Article

\title{
Synthesis, Structural Characterization and Anticancer Activity of New 5-Trifluoromethyl-2-thioxo-thiazolo[4,5-d] pyrimidine Derivatives
}

\author{
Lilianna Becan ${ }^{1, *}$, Anna Pyra ${ }^{2} \mathbb{D}$, Nina Rembiałkowska ${ }^{3} \mathbb{D}$ and Iwona Bryndal ${ }^{1, *} \mathbb{D}$ \\ 1 Department of Organic Chemistry and Pharmaceutical Technology, Faculty of Pharmacy, \\ Wroclaw Medical University, 211A Borowska, 50-556 Wrocław, Poland \\ 2 Faculty of Chemistry, University of Wrocław, 14 Joliot-Curie, 50-383 Wrocław, Poland; \\ anna.pyra@chem.uni.wroc.pl \\ 3 Department of Molecular and Cellular Biology, Faculty of Pharmacy, Wroclaw Medical University, \\ 211A Borowska, 50-556 Wrocław, Poland; nina.rembialkowska@umw.edu.pl \\ * Correspondence: lilianna.becan@umw.edu.pl (L.B.); iwona.bryndal@umw.edu.pl (I.B.)
}

check for updates

Citation: Becan, L.; Pyra, A.; Rembiałkowska, N.; Bryndal, I. Synthesis, Structural Characterization and Anticancer Activity of New 5-Trifluoromethyl-2thioxo-thiazolo[4,5- $d$ ]pyrimidine Derivatives. Pharmaceuticals 2022, 15, 92. https://doi.org/10.3390/ ph15010092

Academic Editors: Luís M. T. Frija and Mary J. Meegan

Received: 2 December 2021 Accepted: 10 January 2022 Published: 13 January 2022

Publisher's Note: MDPI stays neutral with regard to jurisdictional claims in published maps and institutional affiliations.

Copyright: () 2022 by the authors. Licensee MDPI, Basel, Switzerland. This article is an open access article distributed under the terms and conditions of the Creative Commons Attribution (CC BY) license (https:// creativecommons.org/licenses/by/ $4.0 /)$.

\begin{abstract}
Thiazolo[4,5-d]pyrimidine derivatives are considered potential therapeutic agents, particularly in the development of anticancer drugs. In this study, new 7-oxo-(2a-e), 7-chloro-(3a-e) and also three 7-amino-(4a-c) 5-trifluoromethyl-2-thioxo-thiazolo[4,5- $d$ ]pyrimidine derivatives have been synthesized and evaluated for their potential anticancer activity. These derivatives were characterized by spectroscopic methods and elemental analysis, and the single-crystal X-ray diffraction was further performed to confirm a 3D structure for compounds $\mathbf{2 e}$ and $\mathbf{4 b}$. The antiproliferative activity evaluation of twelve new compounds was carried out on a variety of cell lines including four human cancer (A375, C32, DU145, MCF-7/WT) and two normal cell lines (CHO-K1 and $\mathrm{HaCaT})$. Four of them $(\mathbf{2} \mathbf{b}, \mathbf{3 b}, \mathbf{4} \mathbf{b}$ and $\mathbf{4} \mathbf{c})$ were selected by the National Cancer Institute and evaluated for their in vitro anticancer activity using the NCI-60 screening program. 7-Chloro-3-phenyl-5(trifluoromethyl)[1,3]thiazolo[4,5- $d$ ]pyrimidine-2(3H)-thione $(3 \mathbf{b})$ proved to be the most active among the newly synthesized compounds.
\end{abstract}

Keywords: trifluoromethyl derivatives; thiazolo[4,5- $d$ ]pyrimidines; anticancer activity

\section{Introduction}

Fluorinated organic molecules are of exceptional interest in medicinal chemistry [1-3]. The inclusion of fluorine in the molecule often results in improved pharmacological properties [4,5]. At present, fluorinated particles are an important class of anticancer drugs [6]. Fluorine, as a strongly electronegative small substituent, increases lipophilicity and also has an influence on steric effects that change the shape of the molecule. The fluorinated molecule also has greater stability because the $\mathrm{C}-\mathrm{F}$ bond is stronger than the $\mathrm{C}-\mathrm{H}$ bond $[7,8]$. Therefore, it is not quickly degraded by natural enzymes and the biotransformation, especially oxidation, of such substituted compounds is difficult $[9,10]$. With three fluorine atoms, trifluoromethyl moiety is very lipophilic functional group with an electronegative nature [11]. Fluorine is rarely found in natural organic compounds, but drugs containing the trifluoromethyl group are unexpectedly abundant. Drugs with a trifluoromethyl substituent are used in the treatment of many diseases, and as anticancer agents (Figure 1). In 2019, the FDA approved Alpelisib (A), a phosphatidylinositol 3-kinase (PI3K) inhibitor, for use in combination with fulvestrant (B) in the treatment of advanced or metastatic breast cancer [12]. Vilaprisan (C) [13], a synthetic and steroidal selective progesterone receptor modulator, is under investigation for the treatment of leiomyoma. Cevipabulin (D) [14], a polycyclic aromatic compound with potential antineoplastic activity, is a candidate for antitumor clinical trials. Flutamide (E) [15], a non-steroidal anti-androgen, is widely used 
for the treatment of prostate cancer and Sorafenib (F) [16], a multikinase inhibitor, has been shown to be effective in the cure for hepatocellular carcinoma. Here, we describe the structural modification of the 7-thia analogs of purines-thiazolo[4,5- $d$ ]pyrimidinesconsisting of the introduction of a trifluoromethyl moiety into the 5-position of the scaffold. Thiazolo[4,5- $d$ ]pyrimidines, as a purine antagonist, exhibits potential biological activity, including anticancer activity [17-21]. It was expected that a combination of the trifluoromethyl group and thiazolo[4,5- $d$ ]pyrimidine structure in one molecule can create an active compound with good healing properties. According to the records, the introduction of a trifluoromethyl group in the structure could improve the bioavailability of new compounds. A novel series of 5-(trifluoromethyl)-2-thioxo-thiazolo[4,5- $d]$ pyrimidines was synthesized and evaluated for its in vitro cytotoxicity against cancer cell lines. Twelve compounds (2a-e, 3a-d and $\mathbf{4 a - c}$ ) were tested for their antiproliferative potential against four human cancer cell lines and two normal cell lines. In the study, a metabolic test determining mitochondrial activity was used, which determines the proliferative capacity of cells. Four of the prepared compounds, $\mathbf{2 b}, \mathbf{3 b}, \mathbf{4 b}$ and $\mathbf{4 c}$, were selected by the National Cancer Institute (NCI) (Bethesda, MD, USA) under the Development Therapeutic Program for an in vitro screening program in the 60 human cancer cell lines.<smiles>Cc1nc(NC(=O)N2CCCC2C(N)=O)sc1-c1ccnc(C(C)(C)C(F)(F)F)c1</smiles>

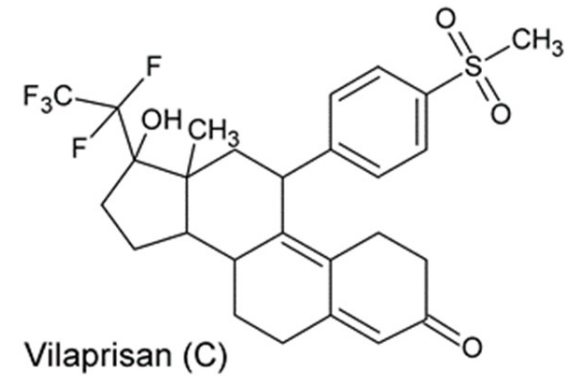<smiles>CC12CCC3c4ccc(O)cc4CC(CCCCCCCCCS(=O)CCCC(F)(F)F)C3C1CCC2O</smiles>

Fulvestrant (B)<smiles>CNCCCOc1cc(F)c(C2C(Cl)=NC3NC=NN3C2NC(C)C(F)(F)F)c(F)c1</smiles><smiles>CC(C)C(=O)Nc1ccc([N+](=O)[O-])c(C(F)(F)F)c1</smiles>

Flutamide (E)

Cevipabulin (D)<smiles>CNC(=O)c1cc(Oc2ccc(NC(=O)Nc3ccc(C)c(C(F)(F)F)c3)cc2)ccn1</smiles>

Figure 1. Drugs with a trifluoromethyl substituent used as anticancer agents: (A) Alpelisib; (B) Fulvestrant; (C) Vilaprisan; (D) Cevipabulin; (E) Flutamide; (F) Sorafenib. 


\section{Results and Discussion}

\subsection{Chemistry}

2.1.1. Synthesis and Physiochemical Properties

The preparation of 5-trifluoromethyl-thiazolo[4,5- $d]$ pyrimidines is depicted in Scheme 1.<smiles>[R]N[As]CC1CC1</smiles><smiles>[R]n1c(N)c(C(N)=O)sc1=S</smiles>

1a-e<smiles>CNc1nc(C(F)(F)F)nc2c1sc(=S)n2-c1ccccc1</smiles><smiles>CN</smiles><smiles>[R]n1c(=O)sc2c(Cl)nc(C(F)(F)F)nc21</smiles><smiles>CCNc1nc(C(F)(F)F)nc2c1sc(=S)n2-c1ccccc1</smiles><smiles></smiles>

\section{$2 a-e$}<smiles>NCc1ccc(CNc2nc(C(F)(F)F)nc3c2sc(=S)n3-c2ccccc2)cc1</smiles>

$\mathrm{R}_{1} \quad \mathrm{a}=\mathrm{C}_{2} \mathrm{H}_{5}, \mathrm{~b}=\mathrm{C}_{6} \mathrm{H}_{5}, \mathrm{c}=2-\mathrm{FC}_{6} \mathrm{H}_{4}, \mathrm{~d}=3-\mathrm{FC}_{6} \mathrm{H}_{4}, \mathrm{e}=4-\mathrm{FC}_{6} \mathrm{H}_{4}$

Scheme 1. Synthetic pathway to 5-trifluoromethyl-thiazolo[4,5- $d]$ pyrimidines.

The starting 4-amino-2-thioxo-2,3-dihydro-3-substituted-1,3-thiazole-5-carboxamides, 1a-e, were prepared in a one-pot reaction from sulphur, 2-cyanoacetamide and appropriate isothiocyanate according to the procedure reported by Gewald [22]. The 3-substituted2-thioxo-5-(trifluoromethyl)-2,3-dihydro[1,3]thiazolo[4,5- $d$ ]pyrimidin-7(6H)-ones 2a-e were obtained using the previously described method [20,22] for the synthesis of 5-methyl derivatives. The source of a $\mathrm{CF}_{3}$ group in our synthesis was trifluoroacetic anhydride. The reaction of thiazole-5-carboxamides 1a-e and the trifluoroacetic anhydride under heating resulted in pyrimidine ring formation and gave the desired thiazolo[4,5- $d$ ]pyrimidine core. In the IR spectra of the cyclized compounds, an absorption band in the region $1122-1166 \mathrm{~cm}^{-1}$ is observed due to stretching vibrations of the $\mathrm{CF}_{3}$ group. Characteristic bands of carbonyl occurred at $1661-1666 \mathrm{~cm}^{-1}$. ${ }^{1} \mathrm{H}-\mathrm{NMR}$ spectra of compounds $2 \mathrm{a}-\mathrm{c}$ exhibit the broad singlet signal attributed to the 6-NH proton, 
observed at $\delta 8.37,12.98$ and $13.85 \mathrm{ppm}$, respectively. In the ${ }^{1} \mathrm{H}-\mathrm{NMR}$ spectra of $\mathbf{2 d}$ and $\mathbf{2 e}$, the $\mathrm{NH}$ proton signal is invisible. Next, chlorination of compounds $2 \mathrm{a}-\mathbf{e}$ with a mixture of phosphorus oxychloride and phosphorus pentachloride was performed at reflux and gave 7-chloro derivatives 3a-e. The IR spectra lacked the carbonyl absorption peaks and, in the region $1700-1716 \mathrm{~cm}^{-1}$, an intense band is observed due to $\mathrm{C}=\mathrm{N}$ stretching vibrations. The ${ }^{1} \mathrm{H}-\mathrm{NMR}$ spectrum for compound $\mathbf{3 a}$ showed a doublet of quartets for the $\mathrm{CH}_{2}$ protons, due to complex coupling. The observed splitting resulted from the coupling of one set of hydrogens to just one set in their neighbor, perhaps due to the steric effects between the ethyl substituents and the fluorine and chlorine atoms in the structure of 3a. Compounds 4 a-c were achieved by the nucleophilic substitution reaction of $\mathbf{3 b}$ with an excess of the appropriate amine.

In all the 7-substituted-amino derivatives, 4a-c, the infrared spectrum exhibited a signal confirming the presence of secondary amine group. The band was observed at $3277-3307 \mathrm{~cm}^{-1}$. The ${ }^{1} \mathrm{H}-\mathrm{NMR}$ spectra revealed the presence of a triplet signal at $8.92-8.56 \mathrm{ppm}$, attributed to the proton of this secondary amine. All newly synthesized compounds gave satisfactory spectral data from ${ }^{1} \mathrm{H}$ - and ${ }^{13} \mathrm{C}-\mathrm{NMR}$ and IR spectroscopy, MS mass spectrometry, and elemental analyses (see Figures S1-S54, in the Supplementary Materials). The spectral data confirmed that the new compounds have the expected structures.

The newly obtained compounds $2 \mathbf{a}-\mathbf{e}$, 3a-e and $4 \mathbf{a}-\mathbf{c}$ do not violate Lipinski's "Rule of 5" for potential drug candidates [23]. The rules state that most molecules with a good bioavailability have a limited lipophilicity, expressed by $\log \mathrm{P} \leq 5$ (octanol/water partition coefficient), a molecular weight MW $\leq 500$, number of hydrogen bond donors $\leq 5$, number of hydrogen bond acceptors $\leq 10$. These parameters, calculated with Molinspiration, are depicted in Table 1 [24].

Table 1. The Lipinski-selected parameters calculated with Molinspiration ${ }^{1}$ for compounds 2a-e, 3a-e and 4a-c.

\begin{tabular}{ccccc}
\hline Compound & MW & LogP & H-Bond Acceptor & H-Bond Donor \\
\hline $\mathbf{2 a}$ & 281.28 & 1.45 & 4 & 1 \\
$\mathbf{2 b}$ & 329.33 & 2.34 & 4 & 1 \\
$\mathbf{2} \mathbf{c}$ & 347.32 & 2.67 & 4 & 1 \\
$\mathbf{2 d}$ & 347.32 & 2.69 & 4 & 1 \\
$\mathbf{2} \mathbf{3}$ & 347.32 & 2.51 & 4 & 1 \\
$\mathbf{3 a}$ & 299.73 & 2.80 & 3 & 0 \\
$\mathbf{3 b}$ & 347.77 & 3.70 & 3 & 0 \\
$\mathbf{3} \mathbf{c}$ & 365.76 & 4.02 & 3 & 0 \\
$\mathbf{3 d}$ & 365.76 & 4.05 & 3 & 0 \\
$\mathbf{3 e}$ & 365.76 & 3.86 & 3 & 0 \\
$\mathbf{4 a}$ & 342.37 & 2.88 & 4 & 1 \\
$\mathbf{4 b}$ & 365.40 & 3.25 & 4 & 1 \\
$\mathbf{4} \mathbf{c}$ & 436.46 & 4.44 & 4 & 1 \\
\hline
\end{tabular}

${ }^{1}$ The Molinspiration Property Calculator.

\subsubsection{Crystal Structures of the Compounds $2 \mathrm{e}$ and $4 \mathrm{~b}$}

Each derivative of $\mathbf{2 a - 2 e}$ can exist in two tautomeric forms (lactam-lactim) with an $\mathrm{NH}$ or $\mathrm{OH}$ group on the pyrimidine ring. Moreover, the ${ }^{1} \mathrm{H}-\mathrm{NMR}$ spectra of the $\mathbf{2} \mathbf{d}$ and 2e signal of the $\mathrm{NH}$ proton are invisible; therefore, additional confirmation was necessary. Despite our efforts, we were unable to obtain $\mathbf{3 b}$ or any of the three monocrystalline derivatives that are suitable for studying the $\mathrm{X}$-ray structure. Therefore, we took steps to obtain 2a-2e derivatives and the last products $(\mathbf{4 a}-\mathbf{4} \mathbf{c})$ of the synthesis in crystalline form. This would enable an unambiguous confirmation of the assumed course of the reaction, and additionally determine which tautomeric form is preferred in the solid state. Compounds $2 \mathbf{e}$ and $\mathbf{4 b}$ were obtained as researchable single crystals; their structures were determined by X-ray crystallography and adopted as a structural model for compounds of groups 2 and 4 , respectively. 
The X-ray diffraction data analysis indicated that 3-(4-fluoropheny)1-2-thioxo-5(trifluoromethyl)-2,3-dihydro[1,3]thiazolo[4,5-d]pyrimidin-7(6H)-one (2e) crystallized as a semi-solvate in the triclinic space group $P-1$. The asymmetric unit was composed of one $2 \mathrm{e}$ molecule (Figure 2) in the lactim form and half of a toluene molecule, which was disordered about the center of symmetry. The thiazolopyrimidine fragment was nearly coplanar and the 4-fluorophenyl ring bound to N3 was rotated with respect to the mean plane of the central ring by $64.4(1)^{\circ}$. In the crystal structure, the molecules of $2 \mathrm{e}$ were linked into a centrosymmetric dimer by N6-H6 $\cdots \mathrm{O}^{\mathrm{i}}$ hydrogen bond $[\mathrm{H} \cdots \mathrm{A}=1.83 \AA$, D $\cdots \mathrm{A}=2.707$ (2) $\AA$, $\mathrm{D}-\mathrm{H} \cdots \mathrm{A}=173^{\circ}$, (i) $-x+1,-y+2,-z+2$ ], involving the atom $\mathrm{H} 6$ of the pyrimidine $\mathrm{NH}$ group as a donor and the carbonyl $\mathrm{O} 7$ atom as an acceptor (Figure 3). Such dimers are further linked via rather weak C-H $\cdots \mathrm{S}[\mathrm{C} 32-\mathrm{H} 32 \cdots \mathrm{S} 2 \mathrm{ii}, \mathrm{H} \cdots \mathrm{A}=2.82 \AA, \mathrm{D} \cdots \mathrm{A}=3.732(2) \AA$, $\mathrm{D}-\mathrm{H} \cdots \mathrm{A}=160^{\circ}$, (ii) $\left.-x,-y+2,-z+1\right]$ and C-H $\cdots \mathrm{F}\left[\mathrm{C} 33-\mathrm{H} 33 \cdots \mathrm{F} 51^{\mathrm{iii}}, \mathrm{H} \cdots \mathrm{A}=2.58 \AA\right.$, $\mathrm{D} \cdots \mathrm{A}=3.480$ (3) $\AA, \mathrm{D}-\mathrm{H} \cdots \mathrm{A}=157^{\circ}$, (iii) $\left.-x,-y+1,-z+1\right]$ interactions (Figure S55). Analysis using PLATON program [25] shows that the aromatic $\pi-\pi$ stacking interactions were also recognized in the $\mathbf{2} \mathbf{e}$ crystal, as may be seen by the comparatively short distance between the centroids of the 4-fluorophenyl [C31-C36 (Cg1)] rings from adjacent molecules $\left[\mathrm{Cg} 1 \cdots \mathrm{Cg} 1^{\mathrm{iii}}=3.8861(17) \AA ̊\right.$.

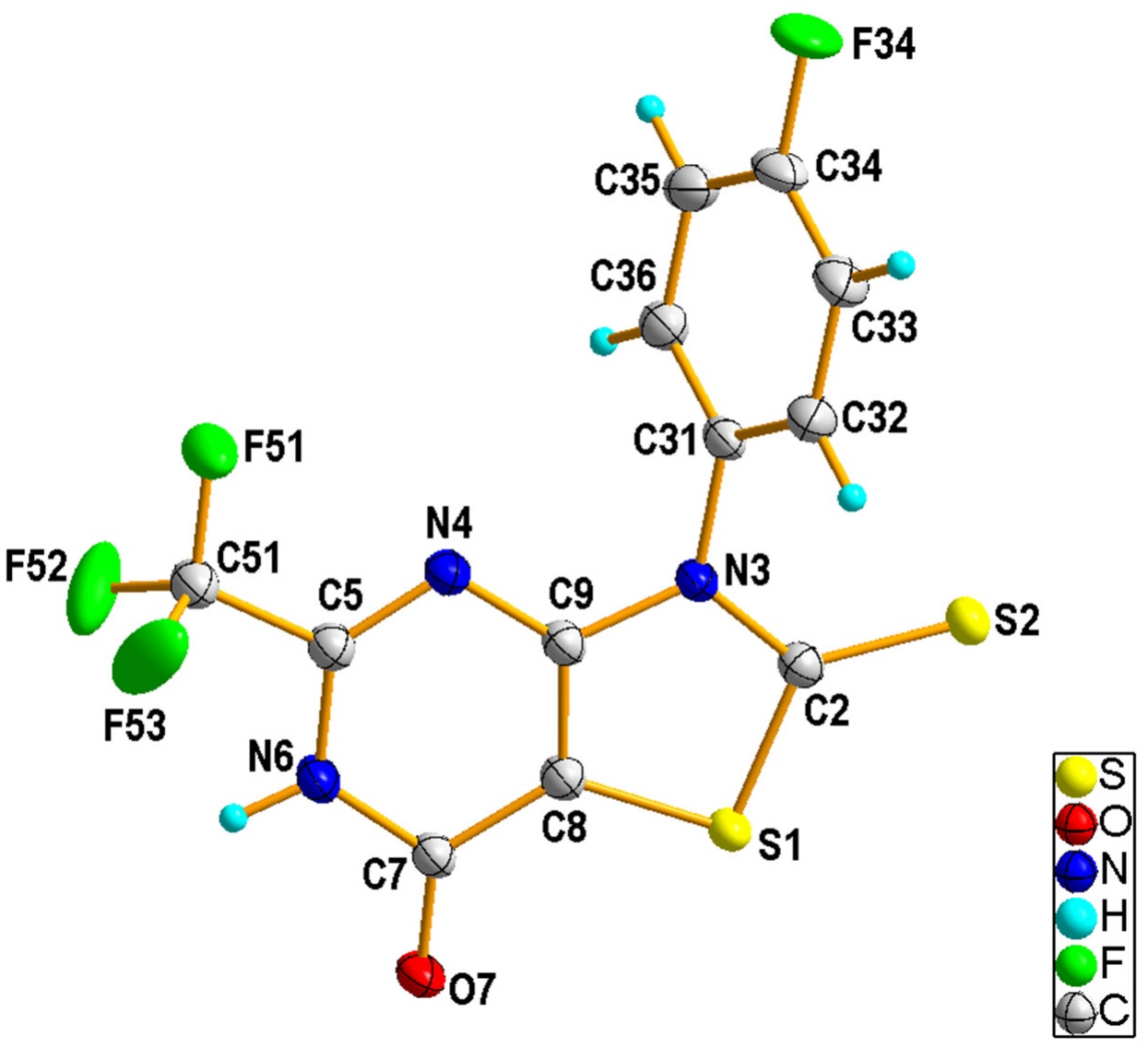

Figure 2. Crystal structure of the 2e molecule showing the atom-numbering scheme and displacement ellipsoids drawn at the $50 \%$ probability level. The disordered toluene molecule was removed for clarity.

Compound $4 \mathrm{~b}$ crystallized in the $P 2_{1} / n$ space group with one molecule in the asymmetric unit (Figure 4). Both the thiazolopyrimidine and the phenyl rings were flat and formed a dihedral angle of $70.8(1)^{\circ}$ to each other. In the crystal of $4 \mathbf{b}, \mathrm{N} 7-\mathrm{H} 7 \cdots \mathrm{S} 2^{\mathrm{i}}$ hydrogen bonds involving the amine $\mathrm{N} 7$ and the thioxo $\mathrm{S} 2$ atoms $[\mathrm{H} \cdots \mathrm{A}=2.52 \AA, \mathrm{D} \cdots \mathrm{A}=3.287(3) \AA$, $\mathrm{D}-\mathrm{H} \cdots \mathrm{A}=147^{\circ}$, (i) $\left.-x+1 / 2, y+1 / 2,-z+3 / 2\right]$ linked the molecules into zig-zag chains running along the $\boldsymbol{b}$-axis (Figure 5 ). The interchain contacts were provided by weak 
$\mathrm{C}-\mathrm{H} \cdots \mathrm{S}\left[\mathrm{C} 36-\mathrm{H} 36 \cdots \mathrm{S} 2^{\mathrm{iii}}, \mathrm{H} \cdots \mathrm{A}=2.75 \AA, \mathrm{D} \cdots \mathrm{A}=3.676\right.$ (4) $\AA, \mathrm{D}-\mathrm{H} \cdots \mathrm{A}=165^{\circ}$, (iii) $x, y+1, z]$ and $\mathrm{C}-\mathrm{H} \cdots \mathrm{F}$ bonds $\left[\mathrm{C} 32-\mathrm{H} 32 \cdots \mathrm{F} 51^{\mathrm{ii}}, \mathrm{H} \cdots \mathrm{A}=2.62 \AA, \mathrm{D} \cdots \mathrm{A}=3.306\right.$ (3) $\AA, \mathrm{D}-\mathrm{H} \cdots \mathrm{A}=129^{\circ}$, (ii) $\left.x, y-1, z\right]$. In addition, the presence of $\mathrm{C}-\mathrm{H} \cdots \pi$ and $\pi \cdots \pi$ interactions completed the rise of the $3 \mathrm{D}$ network.

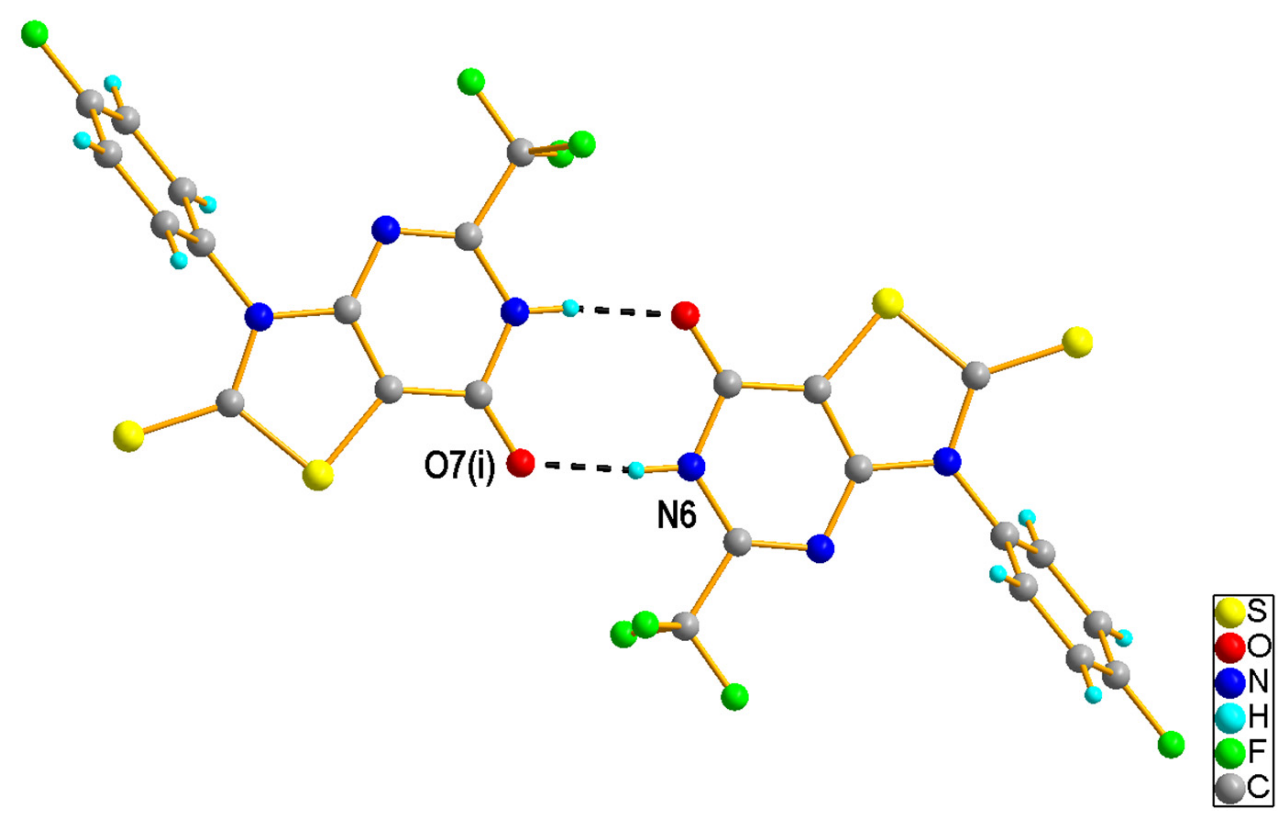

Figure 3. A part of crystal packing of 2e showing the dimer stabilized by $\mathrm{N}-\mathrm{H} \cdots \mathrm{O}$ hydrogen bonds (depicted as black dashed lines).

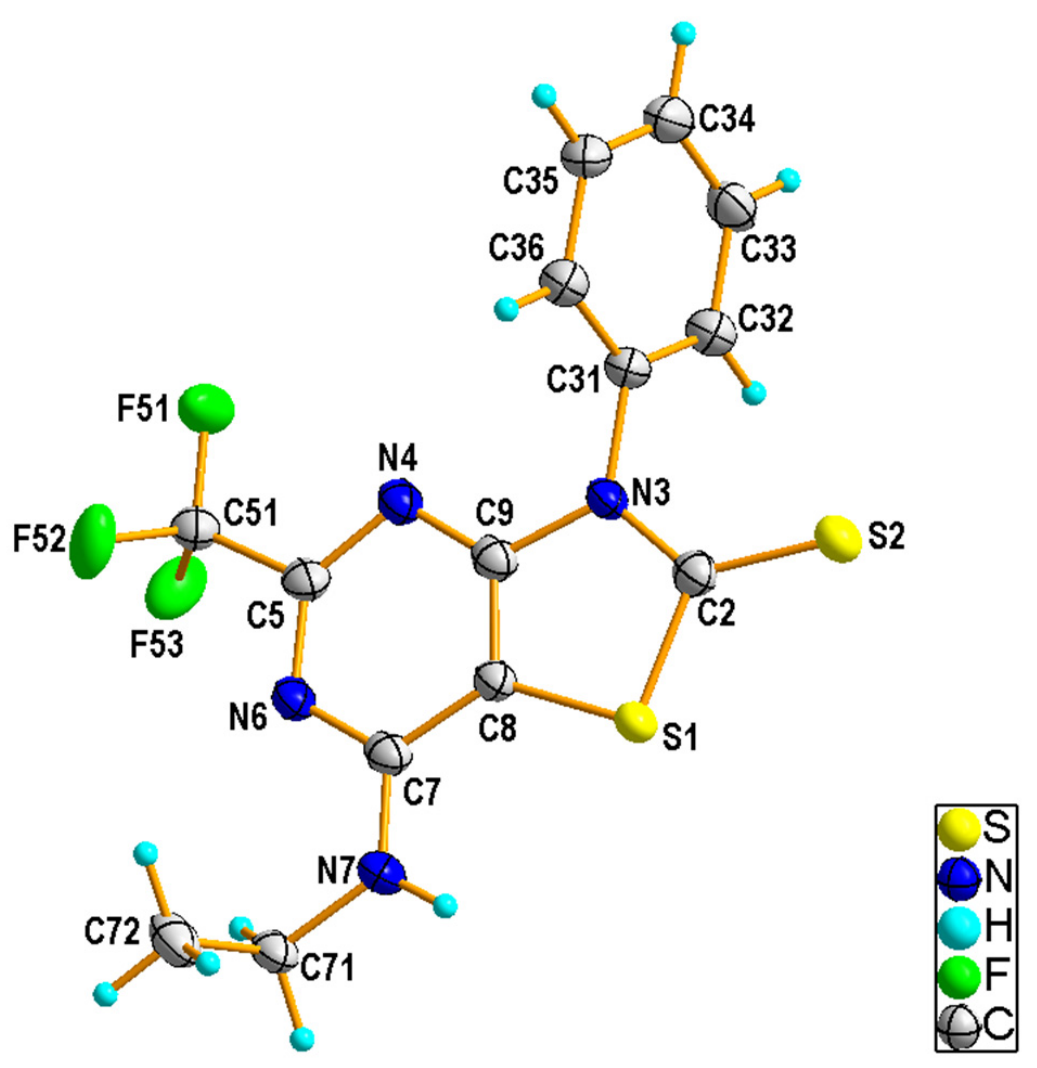

Figure 4. Crystal structure of $4 \mathrm{~b}$ showing the atom-numbering scheme and displacement ellipsoids drawn at the $50 \%$ probability level. 


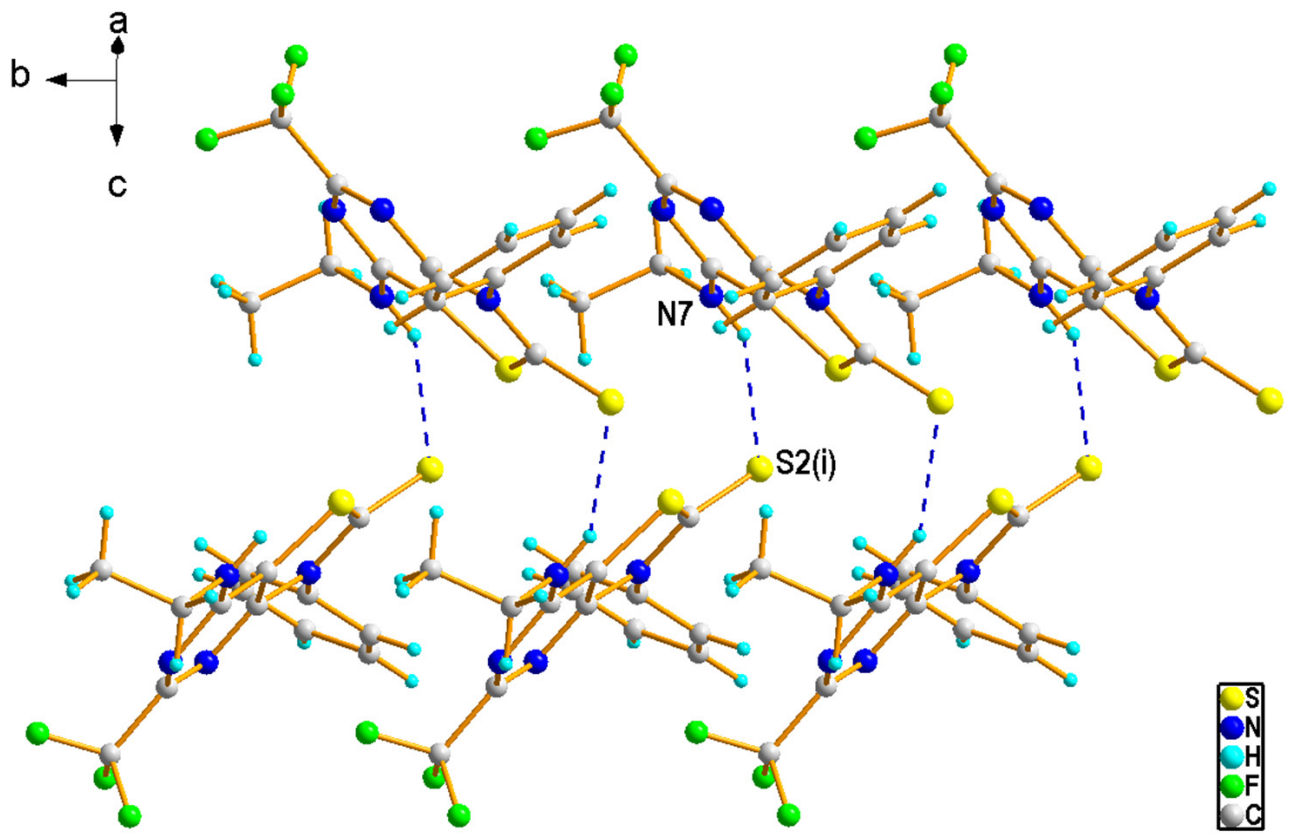

Figure 5. A part of crystal packing of $4 \mathrm{~b}$ showing a zig-zag chain formed by $\mathrm{N}-\mathrm{H} \cdots \mathrm{S}$ interactions (depicted as blue dashed lines).

\subsection{Biological Activity}

\subsubsection{Antiproliferative Activity}

Twelve compounds (2a-e, 3a-d and $4 \mathbf{a}-\mathbf{c}$ ) at a concentration range of 50-5000 $\mu \mathrm{M}$ were tested for their antiproliferative potential against four human cancer cell lines (A375melanotic melanoma, C32-amelanotic melanoma, DU145-prostate cancer androgenindependent, MCF-7/WT-breast adenocarcinoma) and two normal cell lines: Chinese Hamster Ovary (CHO-K1) and immortalized human keratinocytes from histologically normal skin $(\mathrm{HaCaT})$. The results obtained from the exposition of cancer and normal cells to newly synthesized compounds are shown in Figure 6.

The data exhibit the excellent antiproliferative activity of compounds 3a-3d and $4 \mathbf{a}$. The strongest cytotoxic effect was observed after $72 \mathrm{~h}$ incubation of compound $\mathbf{3 b}$ for each of the tested cancer cell lines and for normal cells $(\mathrm{HaCaT})$. The lowest tested concentration $(50 \mu \mathrm{M})$ of compound $3 \mathbf{b}$ reduced the viability to $20 \%$ for melanotic and amelanotic melanoma cell lines and human keratinocytes. A two times higher concentration was seen, as $100 \mu \mathrm{M}$ of compounds from the $\mathbf{3 a - 3 d}$ group also caused a significant decrease in viability. A strong cytotoxic effect was also observed for 3a in C32, DU145 cells and human keratinocytes; for 3c in C32, CHO-K1 cells and human keratinocytes; and for $3 \mathbf{d}$ in C32 cells. The results showed that high cytotoxicity was obtained in DU145 and CHO-K1 cells after $72 \mathrm{~h}$ of incubation with $4 \mathrm{a}$. The most sensitive cell line to the action of tested compounds was DU145, and the most resistant line was MCF-7/WT.

The studied compounds were subjected to the determination of the median growth inhibitory concentration $\left(\mathrm{IC}_{50}\right)$. Table 2 illustrates the $\mathrm{IC}_{50}$ values of compounds $2 \mathbf{2 a}-\mathbf{2 e}$, 3a-3d, 4a-4c toward A375, C32, DU145, MCF-7/WT, CHO-K1 and HaCaT cell lines. The data collected in Table 2 exhibit the excellent growth inhibition of compound $\mathbf{3 b}$ against melanotic and amelanotic melanoma, breast, prostate cancer and keratinocytes cells. The strongest cytotoxic effect was observed for both types of melanoma cancer cells (C32; $\left.\mathrm{IC}_{50}=24.4 \mu \mathrm{M} ; \mathrm{A} 375 ; \mathrm{IC}_{50}=25.4 \mu \mathrm{M}\right)$. In case of normal cells $(\mathrm{CHO}-\mathrm{K} 1$ and HaCaT), $\mathrm{IC}_{50}=75.5 \mu \mathrm{M}$ and $\mathrm{IC}_{50}=33.5 \mu \mathrm{M}$ were acquired, respectively. The most active compounds, 3a-3d, should be further tested to distinguish the type of cell death. One of the important criteria for a cancer therapeutic drug is that its side effects on normal cells in the body are minimized. Our results indicated that compounds $\mathbf{3 a}, \mathbf{3 b}$ and $\mathbf{3} \mathbf{c}$ caused a significant 
decrease in cell viability in both melanoma lines and normal keratinocytes. This effect has not been observed in the case of normal ovarian cells. Interestingly, keratinocytes and melanomas are skin cells and have revealed a higher sensitivity to experimental treatments. This suggests the selectivity of compounds $\mathbf{3} \mathbf{a}, \mathbf{3} \mathbf{b}$ and $\mathbf{3} \mathbf{c}$ for this type of cell. This may be because human skin cells are more susceptible than endodermal cells. Compound $\mathbf{3 d}$, active against both melanoma lines $\left(\mathrm{C} 32 ; \mathrm{IC}_{50}=87.4 \mu \mathrm{M} ; \mathrm{A} 375 ; \mathrm{IC}_{50}=103 \mu \mathrm{M}\right)$, proved to be non-toxic to normal cells (CHO-K1 and $\mathrm{HaCaT}$ ). The largest difference in effect on normal cells was observed for compound 4a: $\mathrm{CHO}-\mathrm{K} 1$ and $\mathrm{HaCaT}, \mathrm{IC}_{50}=48.5$ and $747.5 \mu \mathrm{M}$, respectively. Different cellular responses underlie differences in the action of carcinogenic compounds in different tissues.
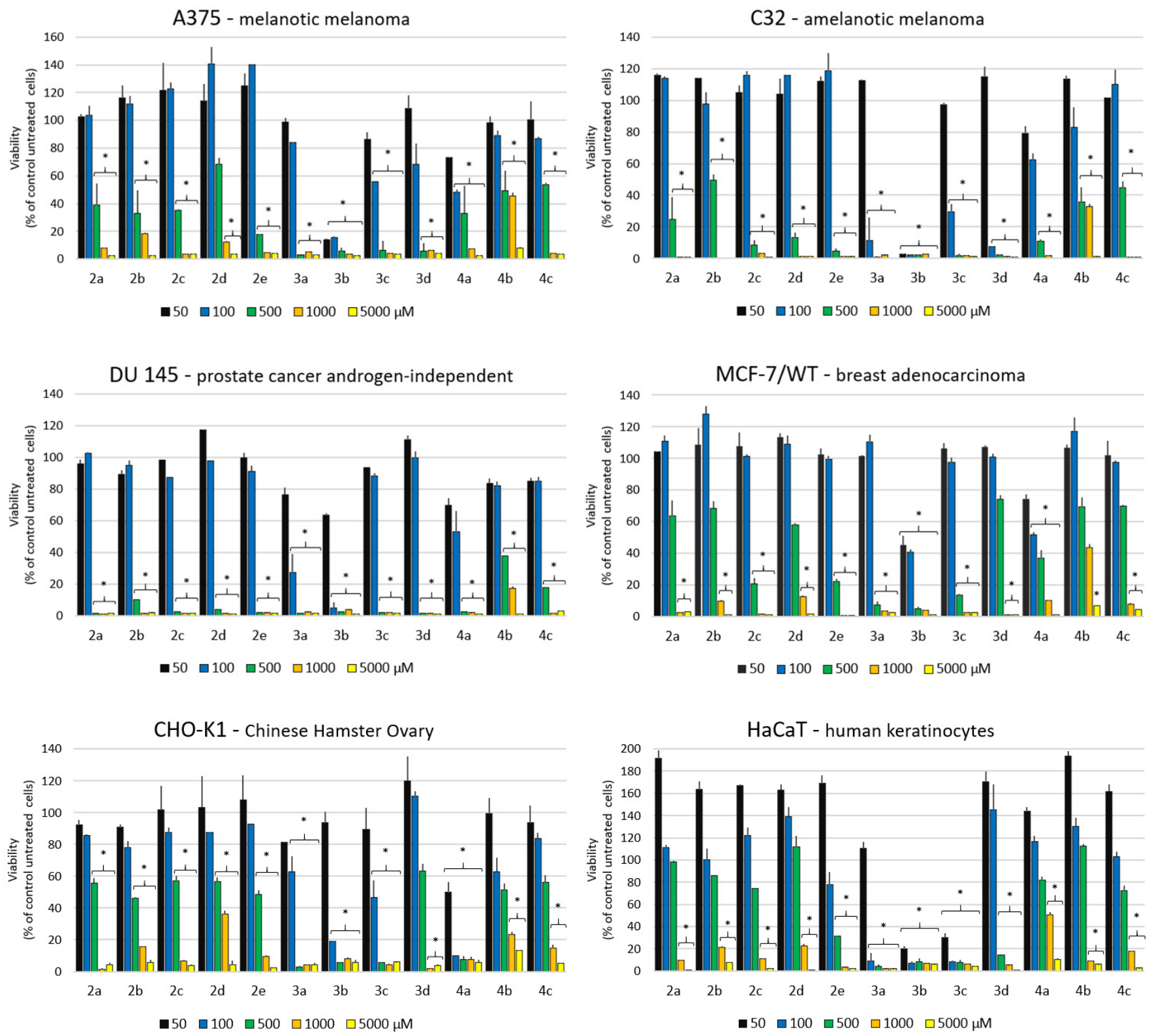

Figure 6. The viability of cancer and normal cells after $72 \mathrm{~h}$ exposition to compounds. The cell viability was determined by the MTT colorimetric assay. The compounds were tested in the 50-5000 $\mu \mathrm{M}$ concentration range. The results are presented as percentage values \pm SD from triplicate determinations, with $p \leq 0.05\left(^{*}\right)$ being considered statistically significant. Various DMSO concentrations were tested; viability results were at control level, data not shown in the graph. 
The lowest values of the mean A (Table 2) refer to $3 b, 3 c$ and $3 a$, respectively. Of all the compounds tested, these three compounds showed the highest toxicity. The lowest value of the mean B occurred for the DU-145 cell line, which showed the highest sensitivity to compounds. The highest value was seen for the normal HACAT line, which may indicate that it is not as susceptible to the effects of the test compounds.

Table 2. The activity of $\mathbf{2 a - 2 e}, \mathbf{3 a}-\mathbf{3 d}$ and $\mathbf{4 a} \mathbf{a}-\mathbf{4}$ compounds in cancer and normal cells, represented as $\mathrm{IC}_{50}(\mu \mathrm{M}) \pm \mathrm{SD}^{*}$.

\begin{tabular}{cccccccc}
\hline Compound & A375 & C32 & DU145 & MCF-7/WT & CHO-K1 & HaCaT & Mean A ** \\
\hline 2a & $429.2 \pm 17.5$ & $434.3 \pm 17.7$ & $251.4 \pm 10.2$ & $519.0 \pm 21.1$ & $520.7 \pm 21.2$ & $615.1 \pm 25.0$ & 461.6 \\
2b & $366.8 \pm 15.1$ & $495.7 \pm 20.4$ & $356.3 \pm 14.7$ & $557.0 \pm 22.9$ & $318.8 \pm 13.1$ & $712.0 \pm 29.3$ & 467.8 \\
2c & $450.2 \pm 17.6$ & $364.2 \pm 14.3$ & $162.8 \pm 6.4$ & $420.2 \pm 16.5$ & $525.2 \pm 20.6$ & $542.9 \pm 21.3$ & 410.9 \\
2d & $531.1 \pm 22.4$ & $383.9 \pm 16.2$ & $120.8 \pm 5.1$ & $518.7 \pm 21.9$ & $552.7 \pm 23.3$ & $724.7 \pm 30.6$ & 472.0 \\
2e & $379.2 \pm 13.5$ & $354.9 \pm 12.6$ & $139.2 \pm 5.0$ & $434.4 \pm 15.5$ & $482.6 \pm 17.2$ & $234.2 \pm 8.3$ & 337.4 \\
3a & $141.8 \pm 3.6$ & $89.3 \pm 2.3$ & $72.5 \pm 1.9$ & $355.5 \pm 9.1$ & $121.6 \pm 3.1$ & $88.3 \pm 2.3$ & 144.8 \\
3b & $25.4 \pm 0.5$ & $24.4 \pm 0.5$ & $55.1 \pm 1.1$ & $49.0 \pm 1.0$ & $75.5 \pm 1.6$ & $33.5 \pm 0.7$ & 43.8 \\
3c & $107.6 \pm 2.6$ & $86.4 \pm 2.1$ & $168.1 \pm 4.0$ & $248.3 \pm 6.0$ & $93.8 \pm 2.3$ & $37.8 \pm 0.9$ & 123.6 \\
3d & $103.9 \pm 3.4$ & $87.4 \pm 2.9$ & $126.4 \pm 4.2$ & $540.0 \pm 17.9$ & $512.3 \pm 17.0$ & $359.8 \pm 11.9$ & 288.3 \\
4a & $113.7 \pm 3.5$ & $132.3 \pm 4.1$ & $96.9 \pm 3.0$ & $143.6 \pm 4.4$ & $48.5 \pm 1.5$ & $747.5 \pm 22.9$ & 213.7 \\
4b & $523.6 \pm 22.3$ & $355.7 \pm 15.2$ & $322.9 \pm 13.8$ & $686.4 \pm 29.3$ & $236.9 \pm 10.1$ & $729.9 \pm 31.1$ & 475.9 \\
4c & $506.6 \pm 22.1$ & $485.2 \pm 21.2$ & $236.6 \pm 10.3$ & $568.1 \pm 24.8$ & $548.6 \pm 24.0$ & $565.0 \pm 24.7$ & 485.0 \\
\hline Mean B *** & 306.6 & 274.5 & 175.8 & 420.0 & 336.4 & 449.2 &
\end{tabular}

* compound concentration that reduces cell proliferation by $50 \%$, as estimated by the MTT assay. The results are presented in micromolar concentration. The data correspond to mean values $( \pm \mathrm{SD})$ for $\mathrm{n} \geq 3 .{ }^{* *}$ Mean $\mathrm{A}$ : the mean $\mathrm{IC}_{50}$ for the given compound. ${ }^{* * *}$ Mean $\mathrm{B}$ : the mean $\mathrm{IC}_{50}$ for the cell line.

\subsubsection{Anticancer Screening Data Analysis}

The search for the cytotoxic activity of new derivatives usually starts with in vitro cell-based screening. Four compounds 2b (NSC D-745983/1), 3b (NSC D-766111/1), 4b (NSC D-785591/1) and 4c (NSC D-771706/1), selected by the National Cancer Institute were tested in the anticancer screen for a panel of approximately 60 human diseaseoriented tumor cell lines, organized into subpanels derived from nine human cancer types-leukemia, melanoma, and cancers of the lung, colon, brain, breast, ovary, prostate, and kidney [26]. They were initially tested at only one concentration of $10 \mu \mathrm{M}\left(10^{-5} \mathrm{M}\right)$ for each cell line, which were inoculated and preincubated on a microtiter plate for $48 \mathrm{~h}$. The results of the one-dose anticancer assay for the tested new compounds are reported as the percentage of the treated cell growth in comparison with untreated no-drug control. This allows for detection of the growth inhibition-values 0-100 and cytotoxicity; negative numbers mean cell death. Derivatives which significantly reduced the growth in the full panel of cell lines were subsequently passed on for evaluation in the main test at a tenfold dilution of five different concentrations, from $10^{-4}$ to $10^{-8} \mathrm{M}$ [27-29].

Table 3 represents a general overview of anticancer activity for the screened derivatives. Compounds $\mathbf{2 b}, \mathbf{4 b}$ and $\mathbf{4 c}$ showed insufficient activity in the one-dose assay; they were devoid of threshold activity and were dropped from the screening program. Compound $\mathbf{2 b}$ demonstrated selective antitumor activity against the individual Ovarian $\mathrm{C}$. cell line IGROV1 (growth\% -5.14). Compounds $\mathbf{4 b}$ and $\mathbf{4} \mathbf{c}$, with 7 -amino substituents, are inactive. A remarkably low mean growth percent value of 29.51 was obtained only for compound $3 \mathbf{b}$. Compound $\mathbf{3 b}$, which possesses electronegative atom $\mathrm{Cl}$, demonstrated much higher average activity against tumor cell lines in comparison with 7-oxo and 7-substituted-amino derivatives. The most sensitive cell lines for this compound are leukemia CCRF-CEM, HL-60(TB) and MOLT-4 (growth\% $-51.41,-41.20$ and -27.71 , respectively), NS cell lung C. HOP-92 and NCI-H522 (growth\% -21.23 and -67.57 , respectively), colon C. HCT-116, HCC-2998 and SW620 (growth\% $-27.21,-26.98$ and -63.05 , respectively), melanoma SK-MEL-28 (growth\% -62.53), ovarian C. OVCAR-3 (growth\% - 41.27), renal C. UO-31 and RFX (growth\% -82.97 and -16.27 ) and breast C. T-47D (growth\% $\%$-35.57). 
Table 3. In vitro anticancer activity for compounds $\mathbf{2 a}, \mathbf{3 b}, \mathbf{4 b}$ and $\mathbf{4 c}$ against 60 human cancer cell lines ${ }^{1}$.

\begin{tabular}{|c|c|c|c|c|c|c|c|}
\hline \multirow[t]{2}{*}{ Panel/Cell Line } & \multicolumn{3}{|c|}{$\begin{array}{l}\text { Growth of Cells } \\
(\%)^{2} 10^{-5} \mathrm{M}\end{array}$} & \multirow{2}{*}{\multicolumn{2}{|c|}{$\log \mathrm{GI}_{50}{ }^{3}$}} & \multirow{2}{*}{$\begin{array}{c}\log \text { TGI }^{4} \\
3 b\end{array}$} & \multirow[t]{2}{*}{$\log L C_{50} 5$} \\
\hline & $2 b$ & $3 b$ & $4 b$ & & & & \\
\hline \multicolumn{8}{|l|}{ Leukemia } \\
\hline CCRF-CEM & 96.48 & -51.41 & -6 & 102.97 & -6.03 & -5.50 & $>-4.00$ \\
\hline HL-60(TB) & 149.39 & -41.20 & 98.91 & 93.41 & -5.81 & -5.41 & - \\
\hline K-562 & 115.47 & 33.07 & 102.59 & 107.45 & -6.16 & -5.36 & $>-4.00$ \\
\hline MOLT-4 & 117.56 & -27.71 & 81.83 & 96.58 & -5.51 & -5.07 & $>-4.00$ \\
\hline RPMI-8226 & 108.14 & 44.45 & - & 104.96 & -5.60 & -5.11 & $>-4.00$ \\
\hline SR & 105.93 & - & 83.46 & 94.72 & -6.36 & -5.70 & $>-4.00$ \\
\hline \multicolumn{8}{|c|}{ Non-SmallCell lung Cancer } \\
\hline A549/ATCC & 103.88 & 91.16 & 74.36 & 98.32 & -5.12 & -4.66 & -4.27 \\
\hline HOP-62 & - & 95.98 & 86.06 & 92.88 & -5.73 & -5.46 & -5.20 \\
\hline HOP-92 & 97.54 & -21.23 & - & 106.96 & -5.90 & -5.56 & -5.23 \\
\hline NCI-H226 & 103.60 & 89.12 & 88.51 & 112.41 & -4.86 & -4.31 & $>-4.00$ \\
\hline NCI-H23 & 112.30 & 99.73 & 93.44 & - & -5.51 & -4.95 & -4.03 \\
\hline NCI-H322M & 128.80 & 101.54 & - & - & -5.42 & -4.90 & -4.42 \\
\hline NCI-H460 & 123.50 & 68.89 & 100.34 & 109.73 & -5.49 & -4.99 & -4.30 \\
\hline NCI-H522 & 90.35 & -67.57 & 70.40 & 90.73 & -6.69 & -6.33 & -5.82 \\
\hline \multicolumn{8}{|l|}{ Colon Cancer } \\
\hline COLO-205 & 114.26 & 30.63 & 105.73 & 112.07 & -5.71 & -5.44 & -5.18 \\
\hline HCT-116 & 102.27 & -27.21 & 94.34 & 111.01 & -5.76 & -5.47 & -5.18 \\
\hline HCT-15 & 106.95 & 2.98 & 94.67 & 103.39 & -5.73 & -5.26 & $>-4.00$ \\
\hline HCC-2998 & 116.48 & -26.89 & 115.06 & 118.24 & -5.65 & -5.31 & -4.89 \\
\hline HT29 & 100.96 & -71.75 & 88.76 & 103.27 & -5.72 & -5.40 & - \\
\hline KM12 & 100.96 & 90.93 & 89.17 & 113.23 & -5.64 & -5.30 & -4.84 \\
\hline SW620 & 95.09 & -63.05 & 106.24 & 114.74 & -5.67 & -5.32 & -4.67 \\
\hline \multicolumn{8}{|l|}{ CNS Cancer } \\
\hline SF-268 & 101.77 & 84.73 & 104.72 & 109.32 & -5.75 & 5.46 & -5.18 \\
\hline SF-295 & 116.63 & - & 94.05 & 91.10 & -4.91 & -4.59 & -4.28 \\
\hline SF-539 & 114.10 & 75.80 & 100.98 & 102.28 & -5.78 & -5.50 & -5.23 \\
\hline SNB-19 & 102.20 & 98.46 & 106.58 & 106.48 & -5.75 & -5.49 & -5.23 \\
\hline SNB-75 & 91.21 & - & 99.24 & 103.11 & -5.70 & -5.38 & -5.05 \\
\hline U251 & 101.63 & - & 93.27 & - & -5.76 & -5.50 & -5.24 \\
\hline \multicolumn{8}{|l|}{ Melanoma } \\
\hline LOX IMVI & 84.58 & 3.11 & 88.57 & 109.59 & -5.75 & -5.48 & -5.21 \\
\hline MALME-3M & 121.70 & 40.72 & 144.23 & 106.31 & -5.64 & -5.37 & -5.09 \\
\hline M14 & 112.91 & 26.96 & 107.61 & 112.06 & -5.70 & -5.39 & -5.08 \\
\hline MDA-MB-435 & 114.64 & 6.26 & 112.84 & 102.86 & -5.73 & -5.43 & -5.13 \\
\hline SK-MEL-2 & 97.36 & 55.66 & 88.08 & 95.77 & -5.70 & -5.42 & -5.14 \\
\hline SK-MEL-28 & 102.86 & -62.53 & 112.46 & 110.02 & -5.71 & -5.45 & -5.19 \\
\hline SK-MEL-5 & - & 81.95 & 87.63 & 105.71 & -5.66 & -5.31 & -4.91 \\
\hline UACC-257 & 107.08 & 19.38 & 98.66 & 96.72 & -5.76 & -5.43 & -5.10 \\
\hline UACC-62 & 109.52 & 79.14 & 93.86 & 105.93 & - & - & - \\
\hline \multicolumn{8}{|l|}{ Ovarian Cancer } \\
\hline IGROV1 & -5.14 & 63.57 & 101.57 & 109.98 & -5.71 & -5.41 & -5.12 \\
\hline OVCAR-3 & 110.35 & -41.27 & 106.99 & 111.62 & -5.72 & -5.47 & -5.22 \\
\hline OVCAR-4 & 117.19 & 23.73 & 98.24 & 125.04 & -5.75 & -5.44 & -5.14 \\
\hline OVCAR-5 & 101.99 & 86.56 & 112.27 & 102.72 & -5.06 & -4.60 & -4.19 \\
\hline OVCAR-8 & 103.45 & 4.40 & 96.11 & 98.68 & -5.71 & -5.27 & $>-4.00$ \\
\hline NCI/ADR-RES & 25.77 & 109.92 & 92.88 & 114.00 & -5.48 & -4.96 & $>-4.00$ \\
\hline SK-OV-3 & 108.53 & 101.94 & 101.70 & 99.96 & -5.31 & -4.97 & $>-4.00$ \\
\hline
\end{tabular}


Table 3. Cont.

\begin{tabular}{|c|c|c|c|c|c|c|c|}
\hline \multirow[t]{2}{*}{ Panel/Cell Line } & \multicolumn{3}{|c|}{$\begin{array}{c}\text { Growth of Cells } \\
(\%)^{2} 10^{-5} \mathrm{M}\end{array}$} & \multicolumn{2}{|c|}{$\log G I_{50}{ }^{3}$} & $\log$ TGI $^{4}$ & \multirow[t]{2}{*}{$\log \mathrm{LC}_{50}{ }^{5}$} \\
\hline & $2 b$ & $3 b$ & $4 b$ & $4 c$ & & $3 b$ & \\
\hline \multicolumn{8}{|l|}{ Renal Cancer } \\
\hline $786-0$ & 104.97 & 90.12 & 101.39 & 99.38 & -5.71 & -5.42 & -5.13 \\
\hline A498 & 90.58 & 91.46 & - & 121.43 & -4.87 & -4.57 & -4.28 \\
\hline $\mathrm{ACHN}$ & 110.42 & 27.40 & 93.13 & 99.14 & -5.76 & -5.48 & -5.20 \\
\hline CAKI-1 & 124.11 & 81.74 & 93.63 & 94.38 & -5.78 & -5.51 & -5.24 \\
\hline SN12C & 106.95 & 85.61 & 100.30 & 101.41 & -5.45 & -4.88 & -4.39 \\
\hline TK-10 & 130.06 & 51.24 & 88.79 & 130.70 & -5.70 & -5.39 & -5.08 \\
\hline UO-31 & 91.22 & -82.97 & 103.75 & 82.87 & -5.77 & -5.49 & -5.22 \\
\hline RXF 393 & 95.34 & -16.27 & 100.09 & 104.44 & -5.74 & -5.47 & -5.21 \\
\hline \multicolumn{8}{|l|}{ Prostate $C}$. \\
\hline PC-3 & 100.88 & 53.66 & - & 100.51 & -5.74 & -5.45 & -5.17 \\
\hline DU-145 & 109.40 & 9.04 & 101.28 & 122.63 & -5.73 & -5.46 & -5.19 \\
\hline \multicolumn{8}{|l|}{ Breast Cancer } \\
\hline MCF7 & 111.19 & 22.84 & 96.38 & 98.77 & -5.65 & -5.25 & -4.24 \\
\hline MDA-MB-231/ATCC & 107.13 & 13.85 & 85.06 & 119.48 & -5.70 & -5.41 & -5.12 \\
\hline HS 578T & 65.01 & 21.84 & 106.83 & 125.43 & -5.55 & -5.07 & $>-4.00$ \\
\hline BT-549 & 130.31 & 73.90 & 95.21 & 98.87 & -5.82 & -5.50 & -5.17 \\
\hline $\mathrm{T}-47 \mathrm{D}$ & 108.41 & -35.57 & 73.92 & 85.37 & -5.73 & -5.32 & -4.18 \\
\hline MDA-MB-468 & 91.37 & 54.38 & 81.60 & 96.15 & -5.77 & -5.45 & -5.13 \\
\hline Mean & 103.88 & 29.51 & 96.94 & 105.13 & & & \\
\hline Mean MG_MID ${ }^{7}$ & & & & & -5.66 & -5.3 & -4.78 \\
\hline
\end{tabular}

The importance of the 5-trifluoromethyl group on thiazolo[4,5- $d$ ]pyrimidine ring was explored by comparing the antiproliferative activity of the newly screened compounds $\mathbf{2} \mathbf{b}$, $3 \mathbf{b}, \mathbf{4 b}$ and $4 \mathbf{c}$, with our previously obtained compounds, which were tested in the NCI, and have a similar structure, as the closest structural analogs I-VII (Figure 7) [30].

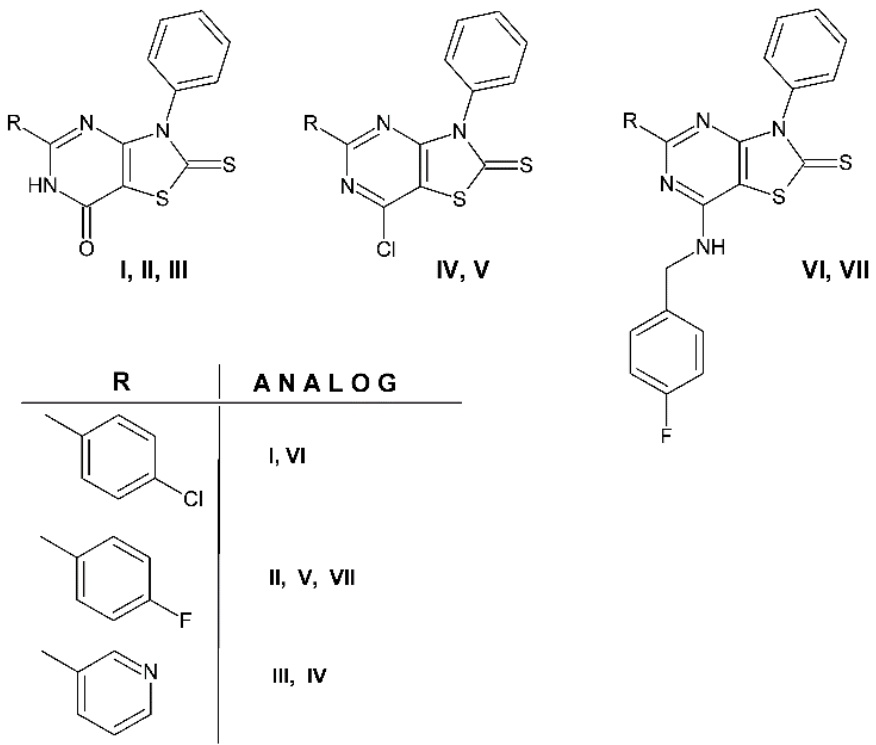

Figure 7. Structural analogs I-VII of new compounds $2 \mathbf{b}, 3 \mathbf{b}$ and $4 \mathbf{c}$. 
Table 4 presents an overview of antitumor activity in one-dose $10^{-5} \mathrm{M}$. 7-Oxo derivatives with trifluoromethyl $\mathbf{2 b}$, heterocyclic III and aromatic I, II. Substituents in the 5-position showed very low activity, with a mean growth percent of tumor cell lines equal to 80-106\%, but 3-phenyl-2-thioxo-5-(trifluoromethyl)-2,3-dihydro[1,3]thiazolo[4,5d]pyrimidin-7 $(6 \mathrm{H})$-one $\mathbf{2} \mathbf{b}$ was more active than its analogs I-III against one single line, IGROV1 (growth\% -5.14). The insertion of a chlorine atom in position 7 of the thiazolo[4,5d]pyrimidine scaffold led to increased activity in these compounds compared to 7-oxo derivatives. The mean growth percent for compounds $\mathbf{3 b}, \mathbf{I V}$ and $\mathbf{V}$ decreased to a value of $20-64 \%$. The derivative IV containing heterocyclic pyridine at the 5-position was the most active in this group. The most sensitive to these 7-chloro derivatives were renal cancer cell lines UO-31 for $\mathbf{3 b}$ and IV, and CAKI-1 for V (growth $\%-82.97,-85,59$ and -88.95 , respectively). Among the compounds with 7-[(4-fluorobenzyl)amino)] moiety 4c, VI and VII, only structural analog VI revealed significant activity against the full panel, with a mean growth percent of $48.46 \%$. It could be that the presence of chlorine atom in the 4-chlorophenyl moiety improves activity.

Table 4. Overview of the one-dose $10^{-5} \mathrm{M}$ assay of new compounds $\mathbf{2} \mathbf{b}, \mathbf{3 b}, \mathbf{4} \mathbf{b}$ and $\mathbf{4} \mathbf{c}$ in comparison with their analogs $\mathbf{I}-\mathbf{V I I}{ }^{1}$.

\begin{tabular}{ccccc}
\hline Compound & $\begin{array}{c}\text { Mean Growth } \\
\mathbf{\%}^{\mathbf{2}} \mathbf{1 0}^{-\mathbf{5}} \mathbf{M}\end{array}$ & $\begin{array}{c}\text { Growth \% of the MOST } \\
\text { Sensitive Cell Line }\end{array}$ & Cancer Type & Cell Line \\
\hline $\mathbf{2 b}$ & 103.88 & -5.14 & Ovarian C. & IGROV1 \\
I & 80.85 & 29.76 & Leukemia & RPMI-8826 \\
II & 106.11 & 55.97 & NS Cell Lung C. & HOP-92 \\
III & 105.59 & 73.81 & NS Cell Lung C. & HOP-92 \\
\hline 3b & 29.51 & -82.97 & Renal C. & UO-31 \\
IV & 20.78 & -85.59 & Renal C. & UO-31 \\
V & 64.11 & -88.95 & Renal C. & CAKI-1 \\
\hline 4b & 96.94 & 70.40 & NS Cell Lung C. & NCI-H522 \\
\hline 4c & 105.13 & 82.87 & Renal C. & UO-31 \\
VI & 48.46 & -43.11 & CNS C. & SF-295 \\
VII & 89.50 & 54.52 & Melanoma & UACC-62 \\
\hline
\end{tabular}

${ }^{1}$ Data obtained from the NCI's disease-oriented human tumor cells. ${ }^{2}$ Values greater than zero mean percentage of growth, less than zero mean percentage of lethality to the tumor cell line.

Antitumor activity in five dose testing $\left(10^{-4}-10^{-8} \mathrm{M}\right)$ is expressed by three different dose-response parameters for each of the 60 human tumor cell lines. The $\mathrm{GI}_{50}$ value (molar concentration causing a half-growth inhibition), TGI (molar concentration required for total growth inhibition), which signifies the cytostatic effect, and $\mathrm{LC}_{50}$ (molar concentration of the compound required for $50 \%$ cell death). LC $_{50}$ signifies the cytotoxic effect. A mean graph midpoint (MG_MID) was calculated for each of these parameters and displays an averaged activity parameter over the full panel of screened tumor cell lines. Table 3 shows the antiproliferative data for four tested compounds $2 \mathbf{b}, \mathbf{3 b}, \mathbf{4 b}$ and $4 \mathbf{c}$ against 60 human cancer cell lines in one dose and main parameters that characterize cytostatic activity for the most active compound $\mathbf{3 b}$. This compound was passed on for extensive evaluation over a five-log dose range and showed very good antitumor properties against all the tested subpanel tumor cell lines at the $\mathrm{GI}_{50}$ and TGI levels, and most at the $\mathrm{LC}_{50}$. 7-Chloro derivative $3 b$ showed moderate selectivity on all 60 cell lines; the values of $\Delta \log$ for three parameters are only slightly larger than 1 . Nevertheless, the selectivity for $\mathrm{GI}_{50}$ can be seen for several cell lines within subpanel leukemia (SR, log $\mathrm{GI}_{50}-6.36$ ) and non-small cell lung cancer (NCI-H522, log $\left.\mathrm{GI}_{50}-6.69\right)$. Compound $\mathbf{3 b}$ demonstrated the highest cytotoxic activity for the melanoma, CNS and renal cancer among the tested subpanels tumor cell lines at the $\mathrm{LC}_{50}$ indicator. Table 5 demonstrates an overview of the main parameters that characterize cytostatic activity for the most active new compound, $\mathbf{3 b}$, and its analogs, IV and $\mathbf{V}$. 
Table 5. Overview of the results of the in vitro anticancer activity for compound $\mathbf{3 b}$ in comparison with analogs IV and $\mathbf{V}^{1}$.

\begin{tabular}{|c|c|c|c|c|c|c|c|c|c|c|}
\hline \multicolumn{11}{|c|}{ Number of Cell Lines Giving Positive $\log \mathrm{GI}_{50}{ }^{2}, \log \mathrm{TGI}^{3}, \log \mathrm{LC}_{50}{ }^{4}(\leq-4.01)$} \\
\hline \multirow{2}{*}{ Cd } & \multirow{2}{*}{$\mathbf{N}$} & \multicolumn{3}{|c|}{$\log \mathrm{GI}_{50}$} & \multicolumn{3}{|c|}{$\log$ TGI } & \multicolumn{3}{|c|}{$\log \mathrm{LC}_{50}$} \\
\hline & & N1 & Range $^{5}$ & MG_MID ${ }^{6} / \Delta^{7}$ & N2 & Range & MG_MID/ $\Delta$ & N3 & Range & MG_MID/ $\Delta$ \\
\hline $3 b$ & 58 & 58 & -4.86 to -6.69 & -5.495146 & 58 & -4.31 to -6.33 & -5.145631 & 45 & -4.03 to -5.82 & -4.596153846 \\
\hline IV & 59 & 37 & -5.28 to -6.26 & -6.728395 & 7 & -4.52 to -5.51 & $4.39 / 1.12$ & 3 & -5.17 to -5.26 & -3.317073171 \\
\hline $\mathbf{V}$ & 59 & 58 & -4.23 to -8.00 & -5.097087 & 49 & -4.10 to -5.90 & -4.663366 & 35 & -4.07 to -5.42 & -4.631578947 \\
\hline
\end{tabular}

$\mathrm{N}$-number of tested human tumor cell lines; N1,2,3-number of cell lines with positive log GI50, $\log \mathrm{TGI}, \log \mathrm{LC}_{50}$

${ }^{1}$ Data obtained from the NCI's in vitro human tumor cell screening. ${ }^{2}$ The log of the molar concentration that inhibits $50 \%$ net cell growth. ${ }^{3}$ The log of the molar concentration leading to total growth inhibition. ${ }^{4}$ The $\log$ of the molar concentration leading to $50 \%$ net cell death. ${ }^{5}$ Range the values $>-4.00$ were excluded. ${ }^{6}$ Mean graph midpoint $=$ arithmetical mean value for all tested cancer cell lines. ${ }^{7}$ The logarithmic difference between the parameter value referred to the most sensible cell line and the MG_MID value. Delta is considered low if $<1$, moderate $1-3$, high if $>3$.

As can be seen from Table 1, the 7-chloro active compounds 3a-3e have greater lipophilicity than their 7-oxo analogs $2 \mathrm{a}-2 \mathrm{e}$ However, the inactive compound $4 \mathrm{c}$ is also characterized by high lipophilicity, i.e., it cannot be a property that determines the activity for this group of compounds. From the analysis of the data reported in Tables 3-5, we can evince that chlorine atom on the 7 position of thiazolo[4,5- $d$ ]pyrimidine ring, rather than a substituent on the 5 position, appears to favorably modulate anticancer activity. The change in the chlorine atom from the 7-position to an amino group leads to the inactive compounds $4 \mathbf{b}$ and $4 \mathbf{c}$. The comparison of the main parameters that characterize the cytostatic activity of the tested compounds, trifluoromethyl $\mathbf{3 b}$ and its analogs IV and $\mathbf{V}$ from our previous paper, revealed a number of observations. As shown in Table 4, the mean percent growth of tumor cell lines at a dose of $10^{-5} \mathrm{M}$ for analog IV and the trifluoromethyl derivative $\mathbf{3 b}$ is comparable. Nevertheless, the trifluoromethyl derivative $\mathbf{3 b}$ exhibited the highest average anticancer activity (MIG_MID $\log \mathrm{GI}_{50}-5.66, \log \mathrm{TGI}-5.30, \log \mathrm{LC}_{50}-4.38$ ) and demonstrated cytostatic activity against all 58 tested cell lines ( $\left.\mathrm{GI}_{50}, \mathrm{TGI}\right)$ and cytotoxic effects relative to 45 cell lines $\left(\mathrm{LC}_{50}\right)$ tested with it. Analog $\mathbf{V}$ showed good results, with 58,49 and 35 cell lines, whereas IV demonstrated cytotoxicity ( $\left.\mathrm{LC}_{50}\right)$ against only 3 of the 59 tested cell lines. From these data, collected in Table 5, the cytotoxic activity of the trifluoromethyl derivative $\mathbf{3 b}$ is shown to be comparable to its structural analogs IV and V. The trifluoromethyl substituent does not have as much influence on the activity of the thiazolo[4,5- $d]$ pyrimidine derivatives as was assumed.

\section{Materials and Methods}

\subsection{Chemistry}

Melting points were determined on a Mel-Temp apparatus and are uncorrected. The IR spectra were recorded on a Nicolett FT-IR spectrometer and are reported in $\mathrm{cm}^{-1}$. The ${ }^{1} \mathrm{H}$ - and ${ }^{13} \mathrm{C}-\mathrm{NMR}$ spectra were recorded on a BRUKER ARX $300 \mathrm{MHz}$ instrument using dimethyl sulfoxide-d6 or $\mathrm{CDCl}_{3}$ as a solvent. All chemical shifts are reported in a ppm down field relative to the chemical shifts in teramethylsilane. The progress of the reaction and the purity of obtained compounds were monitored by thin-layer chromatography (TLC) on Merck silica gel plates (Merck $\mathrm{F}_{254}$, Darmstadt, Germany), using the solvent system ethyl acetate:hexane 1:1 for eluation. Elemental analyses were performed on a Perkin Elmer analyzer (Waltham, MA, USA); the results are within $\pm 0.4 \%$ of the calculated values. Molecular weight of final compounds was assessed by electrospray ionization mass spectrometry from Bruker Daltonics (Billerica, MA, USA). The reagents and chemicals for synthesis were purchased from commercial sources and used with no further purification from Alfa Aesar (Ward Hill, MA, USA), Sigma Aldrich (Burlington, MA, USA) or Chempur (Bangalore, India). 


\subsubsection{Preparation of Compounds 1a-1e}

The starting thiazoles 1a-e were prepared according to known procedures, described in references $[20,22,30]$. Appropriate isothiocyanate $(100 \mathrm{nM})$ was added dropwise to a stirred suspension of cyanoacetamide $(8.4 \mathrm{~g}, 100 \mathrm{mM})$, sulphur $(3.2 \mathrm{~g}, 100 \mathrm{mM})$ and trimethylamine $(12 \mathrm{~mL})$ in ethanol $(100 \mathrm{~mL})$. Next, the mixture was stirred at $50-60{ }^{\circ} \mathrm{C}$ for $1 \mathrm{~h}$ and, after cooling, the precipitated product was filtered, washed with cold ethanol and recrystallized from glacial acetic acid.

4-amino-3-ethyl-2-thioxo-2,3-dihydro-1,3-thiazole-5-caboxamide (1a). Grey needles; Yield $87 \%$, m.p. $182-183^{\circ} \mathrm{C}[30]$.

4-amino-3-phenyl-2-thioxo-2,3-dihydro-1,3-thiazole-5-carboxamide (1b). Pale yellow needles; Yield 67\%, m.p. $247-248{ }^{\circ} \mathrm{C}$ [22].

4-amino-3-(2-fluorophenyl)-2-thioxo-2,3-dihydro-1,3-thiazole-5-caboxamide (1c). Yellow needles; Yield 67\%, m.p. $237-238{ }^{\circ} \mathrm{C} .{ }^{1} \mathrm{H}-\mathrm{NMR}$ (DMSO) $8: 7.65-7.40(\mathrm{~m}, 4 \mathrm{H}), 7.11\left(\mathrm{~s}, 2 \mathrm{H}, \mathrm{NH}_{2}\right)$, $6.95\left(\mathrm{~s}, 2 \mathrm{H}, \mathrm{NH}_{2}\right)$.

4-amino-3-(3-fluorophenyl)-2-thioxo-2,3-dihydro-1,3-thiazole-5-caboxamide (1d). Yellow needles; Yield 67\%, m.p. $222-223{ }^{\circ} \mathrm{C} .{ }^{1} \mathrm{H}-\mathrm{NMR}$ (DMSO) 8: 7.66-7.20 (m, 4H), 7.07 (s, 2H, $\left.\mathrm{NH}_{2}\right), 6.85\left(\mathrm{~s}, 2 \mathrm{H}, \mathrm{NH}_{2}\right)$.

4-amino-3-(4-fluorophenyl)-2-thioxo-2,3-dihydro-1,3-thiazole-5-caboxamide (1e). Yellow needles; Yield $84 \%$, m.p. $270-272{ }^{\circ} \mathrm{C}$ [20].

\subsubsection{Preparation of Compounds 2a-2e}

For the cyclocondensation reaction, a mixture of appropriate thiazole 1a-e $(10 \mathrm{mM})$ and $20 \mathrm{~mL}$ of trifluoroacetic anhydride was heated at reflux with stirring for $4 \mathrm{~h}$ and was kept at room temperature overnight. The precipitate was separated by filtration and then recrystallized from toluene.

3-ethyl-2-thioxo-5-(trifluoromethyl)-2,3-dihydro[1,3]thiazolo[4,5-d]pyrimidin-7(6H)-one

(2a). Orange solid, yield 62\%, m.p. $229-230{ }^{\circ} \mathrm{C} .{ }^{1} \mathrm{H}-\mathrm{NMR}$ (DMSO) $\delta: 8.37(\mathrm{~s}, 1 \mathrm{H}, \mathrm{NH})$, $4.34\left(\mathrm{q}, J=21.3 \mathrm{~Hz}, 2 \mathrm{H}, \mathrm{CH}_{2}\right), 1.26\left(\mathrm{t}, J=14.1 \mathrm{~Hz}, 3 \mathrm{H}, \mathrm{CH}_{3}\right) ;{ }^{13} \mathrm{C}-\mathrm{NMR}$ (DMSO) $\delta: 12.26$ (x2C), 107.06, 117.64, 121.29, 159.02, 161.83, 189.21. IR cm $\mathrm{cm}^{-1}$ : 3364, 1661, 1548, 1122, 739. MS (ESI, $m / z$ ) $[\mathrm{M}-\mathrm{H}]^{-}$calcd. for $\mathrm{C}_{8} \mathrm{H}_{6} \mathrm{~F}_{3} \mathrm{~N}_{3} \mathrm{OS}_{2} 279.9821$; found 279.9891. Anal. calcd. C 34.16, H 2.15, N 14.94; found C 34.09, H 2.30, N 14.68\%.

3-phenyl-2-thioxo-5-(trifluoromethyl)-2,3-dihydro[1,3]thiazolo[4,5-d]pyrimidin-7(6H)-one (2b). Yellow solid, yield 74\%, m.p. $262-263{ }^{\circ} \mathrm{C} .{ }^{1} \mathrm{H}-\mathrm{NMR}$ (DMSO) $\delta: 12.98$ (s, 1H, NH), 7.61-7.37 (m, 5H, Ar-H); ${ }^{13} \mathrm{C}-\mathrm{NMR}$ (DMSO) $\delta: ~ 106.73,117.03,120.68,128.60,129.51,129.79,135.14$, 151.61, 152.10, 159.76, 161.35, 190.04. IR cm ${ }^{-1}: 3050,1662,1587,1146,732$. MS (ESI, $\left.m / z\right)$ $[\mathrm{M}-\mathrm{H}]^{-}$calcd. for $\mathrm{C}_{12} \mathrm{H}_{6} \mathrm{~F}_{3} \mathrm{~N}_{3} \mathrm{OS}_{2} 327.9821$; found 327.9853. Anal. calcd. C 43.77, $\mathrm{H} 1.84, \mathrm{~N}$ 12.76; found C $44.09, \mathrm{H} 1.75, \mathrm{~N} 12.48 \%$.

3-(2-fluoropheny)l-2-thioxo-5-(trifluoromethyl)-2,3-dihydro[1,3]thiazolo[4,5-d]pyrimidin-7(6H)one (2c). Yellow solid, yield 66\%, m.p. $211-212{ }^{\circ} \mathrm{C} .{ }^{1} \mathrm{H}-\mathrm{NMR}$ (DMSO) $\delta: 13.08$ (s, 1H, $\mathrm{NH}), 7.69-7.40(\mathrm{~m}, 4 \mathrm{H}, \mathrm{Ar}-\mathrm{H}) ;{ }^{13} \mathrm{C}-\mathrm{NMR}$ (DMSO) $\delta: 107.52,117.45,121.11,122.94,126.04$, 131.44, 133.08, 151.42, 152.45, 155.79, 162.13, 190.44. IR cm ${ }^{-1}: 3433,3321,1654,1596,1154$, 733. MS (ESI, $m / z$ ) [M-H] $]^{-}$calcd. for $\mathrm{C}_{12} \mathrm{H}_{5} \mathrm{~F}_{4} \mathrm{~N}_{3} \mathrm{OS}_{2}$ 345.9737; found: 345.9887. Anal. calcd. C 41.50, H 1.45, N 12.10; found C 41.88, H 1.75, N 12.47\%.

3-(3-fluorophenyl)-2-thioxo-5-(trifluoromethyl)-2,3-dihydro[1,3]thiazolo[4,5-d]pyrimidin-7(6H)one (2d). Yellow solid, yield 61\%, m.p. $263-264{ }^{\circ} \mathrm{C} .{ }^{1} \mathrm{H}-\mathrm{NMR}$ (DMSO) $\delta: 7.70-7.12(\mathrm{~m}, 4 \mathrm{H}$, Ar-H); ${ }^{13}$ C-NMR (DMSO) $\delta: 107.17,116.93,125.76,128.65,129.35,131.74,136.92,160.44$, 160.91, 161.98, 164.15, 190.82. IR cm${ }^{-1}: 3052,1666,1599,1153,729$. MS (ESI, $\left.m / z\right)[\mathrm{M}-\mathrm{H}]^{-}$ calcd. for $\mathrm{C}_{12} \mathrm{H}_{5} \mathrm{~F}_{4} \mathrm{~N}_{3} \mathrm{OS}_{2}$ 345.9726; found 345.9832. Anal. calcd. C 41.50, H 1.45, N 12.10; found C $41.79, \mathrm{H} 1.68, \mathrm{~N} 12.32 \%$.

3-(4-fluoropheny)l-2-thioxo-5-(trifluoromethyl)-2,3-dihydro[1,3]thiazolo[4,5-d]pyrimidin-7(6H)one (2e). Yellow solid, yield 63\%, m.p. ${ }^{259-260}{ }^{\circ} \mathrm{C} .{ }^{1} \mathrm{H}-\mathrm{NMR}\left(\mathrm{CDCl}_{3}\right)$ 8: $7.32-7.17(\mathrm{~m}$, $4 \mathrm{H}, \mathrm{Ar}-\mathrm{H}) ;{ }^{13} \mathrm{C}-\mathrm{NMR}\left(\mathrm{CDCl}_{3}\right) \delta: 116.83,117.15,121.03,125.30,128,23,129.04,130.23,130.35$, $133.31,137.88,142.32,160.17 . \mathrm{IR} \mathrm{cm}^{-1}: 3055,1668,1556,1166,732 . \mathrm{MS}$ (ESI, $\left.m / z\right)[\mathrm{M}-\mathrm{H}]^{-}$ 
calcd. for $\mathrm{C}_{12} \mathrm{H}_{5} \mathrm{~F}_{4} \mathrm{~N}_{3} \mathrm{OS}_{2}$ 345.9726; found 345.9803. Anal. calcd. C 41.50, H 1.45, N 12.10; found C 41.16, H 1.62, N $12.47 \%$.

\subsubsection{Preparation of Compounds 3a-3e}

For the chlorination reaction, the appropriate 3-substituted-2-thioxo-5-(trifluoromethyl)2,3-dihydro[1,3]thiazolo[4,5-d]pyrimidin-7(6H)-one 2a-e (10 mM) was added to a solution of phosphorus pentachloride $(2.08 \mathrm{~g}, 10 \mathrm{nM})$ in $20 \mathrm{~mL}$ of phosphorus oxychloride. The mixture was heated under reflux for $2 \mathrm{~h}$ and, after cooling, poured into $200 \mathrm{~mL}$ of ice-water. Then, it was filtered, washed with water, dried, and recrystallized from glacial acetic acid.

7-chloro-3-ethyl-5-(trifluoromethyl)[1,3]thiazolo[4,5-d]pyrimidine-2(3H)-thione (3a). Yellow solid, yield 60\%, m.p. $66-67^{\circ} \mathrm{C} .{ }^{1} \mathrm{H}-\mathrm{NMR}$ (DMSO) $\delta: ~ 4.42-3.97(\mathrm{dq}, J=21.6, J=21.6,2 \mathrm{H}$, $\left.\mathrm{CH}_{2}\right), 1.27\left(\mathrm{t}, J=19.8 \mathrm{Mz}, 3 \mathrm{H}, \mathrm{CH}_{3}\right) ;{ }^{13} \mathrm{C}-\mathrm{NMR}$ (DMSO) $\delta: 11.92,12.86,107.04,117.53,121.17$, $150.13,158.02,166,80,189.35$. IR cm ${ }^{-1}: 1709,1548,1343,1154,739$. MS (ESI, $\left.m / z\right)[\mathrm{M}-\mathrm{H}]^{-}$ calcd. for $\mathrm{C}_{8} \mathrm{H}_{5} \mathrm{ClF}_{3} \mathrm{~N}_{3} \mathrm{~S}_{2}$ 298.9482; found 298.9494. Anal. calcd. C 32.06, H 1.68, N 14.02; found C $32.10, \mathrm{H} 1.84, \mathrm{~N} 14.25 \%$.

7-chloro-3-phenyl-5-(trifluoromethyl)[1,3]thiazolo[4,5-d]pyrimidine-2(3H)-thione (3b). Yellow solid, yield 72\%, m.p. $132-133{ }^{\circ} \mathrm{C} .{ }^{1} \mathrm{H}-\mathrm{NMR}$ (DMSO) $8: 7.67-7.50$ (m, 5H, Ar-H); ${ }^{13}$ C-NMR (DMSO) $8:$ 127.74, 128.34, 129.54, 129.79, 129.89, 130.26, 132.58 134.52, 150.48, 158.11, 166.34, 190.23. IR cm ${ }^{-1}: 1700,1541,1342,1150,732$. MS (ESI, $\left.m / z\right)[\mathrm{M}-\mathrm{H}]^{-}$calcd. for $\mathrm{C}_{12} \mathrm{H}_{5} \mathrm{ClF}_{3} \mathrm{~N}_{3} \mathrm{~S}_{2}$ 345.9482; found 345.9508. Anal. calcd. C 41.44, H 1.45, N 12.08; found C 41.56, H 1.54, N 11.93\%.

7-chloro-(2-fluoropheny)-5-(trifluoromethyl)[1,3]thiazolo[4,5-d]pyrimidine-2(3H)-thione (3c). Yellow solid, yield 56\%, m.p. $140-141{ }^{\circ} \mathrm{C} .{ }^{1} \mathrm{H}-\mathrm{NMR}$ (DMSO) $\delta: 7.65-7.43$ (m, 4H, arom.); ${ }^{13}$ C-NMR (DMSO) $8:$ 117.44, 117.67, 126.08, 126.32, 128.65, 129.35, 131.46, 151.42, 159.58, 162.23, 164.01, 190.43. IR cm ${ }^{-1}: 1712,1542,1115,734$. MS (ESI, $\left.m / z\right)[\mathrm{M}-\mathrm{H}]^{-}$calcd. for $\mathrm{C}_{12} \mathrm{H}_{4} \mathrm{ClF}_{4} \mathrm{~N}_{3} \mathrm{~S}_{2}$ 363.9388; found 363.9448. Anal. calcd. C 39.41, H 1.10, N 11.49; found C $39.64, \mathrm{H} 1.20, \mathrm{~N} 11.88 \%$.

7-chloro-(3-fluoropheny)-5-(trifluoromethyl)[1,3]thiazolo[4,5-d]pyrimidine-2(3H)-thione (3d). Yellow solid, yield 72\%, m.p. $128-129{ }^{\circ} \mathrm{C} .{ }^{1} \mathrm{H}-\mathrm{NMR}$ (DMSO) $8: 7.73-7.36$ (m, 4H, Ar-H); ${ }^{13}$ C-NMR (DMSO) $8: 116.60$ 117.90, 124.71, 132.14, 134.12, 136.05, 151.73, 158.35, 160.73, 163.99, 166.57, 190.54. IR cm ${ }^{-1}$ : 1716, 1544, 1194, 730. MS (ESI, $\left.m / z\right)[\mathrm{M}-\mathrm{H}]^{-}$calcd. for $\mathrm{C}_{12} \mathrm{H}_{4} \mathrm{ClF}_{4} \mathrm{~N}_{3} \mathrm{~S}_{2}$ 363.9388; found: 363.9478. Anal. Calc: $\mathrm{C}, 39.41 ; \mathrm{H}, 1.10 ; \mathrm{N}, 11.49 \%$. Found $\mathrm{C}, 39,47 ; \mathrm{H}, 0.98 ; \mathrm{N}, 11.91 \%$.

7-chloro-(4-fluoropheny)-5-(trifluoromethyl)[1,3]thiazolo[4,5-d]pyrimidine-2(3H)-thione (3e). Yellow solid, yield 72\%, m.p. 147-148 ${ }^{\circ} \mathrm{C} .{ }^{1} \mathrm{H}-\mathrm{NMR}$ (DMSO) $\delta: ~ 7.63-7.44(\mathrm{~m}, 4 \mathrm{H}, \mathrm{Ar}-\mathrm{H})$; ${ }^{13}$ C-NMR (DMSO) $8: 117.38,117.52,120.08,129.23,130.61,150.98,151.71,158.62,161.19$, 164.46, 166.84, 190.89. IR cm ${ }^{-1}: 1711,1542,1115,734$. MS (ESI, $\left.m / z\right)[\mathrm{M}+\mathrm{H}]^{+}$calcd. for $\mathrm{C}_{12} \mathrm{H}_{4} \mathrm{ClF}_{4} \mathrm{~N}_{3} \mathrm{~S}_{2}$ 363.9388; found 363.9498. Anal. calcd. C 39.41, H 1.10, N 11.49; found C $39.34, \mathrm{H} 0.95, \mathrm{~N} 11.43 \%$.

\subsubsection{Preparation of Compounds $4 a-4 c$}

For the reaction of $\mathbf{3 b}$ with amines, the selected amine $(20 \mathrm{mM})$ was added to a suspension of $3 \mathbf{b}(3.45 \mathrm{~g}, 10 \mathrm{mM})$ in $20 \mathrm{~mL}$ of buthan-1-ol. The mixture was refluxed for $3 \mathrm{~h}$, then cooled, and the obtained solid was filtered and recrystallized from buthan-1-ol.

7-(methylamino)-3-phenyl-5-(trifluoromethyl)[1,3]thiazolo[4,5-d]pyrimidine-2(3H)-thione (4a). Yellow solid, yield 65\%, m.p. $197-198{ }^{\circ} \mathrm{C} .{ }^{1} \mathrm{H}-\mathrm{NMR}$ (DMSO) $\delta: 8.56(\mathrm{t}, 1 \mathrm{H}, \mathrm{NH}), 7.58-7.40$ (m, 5H, Ar-H), 2.98 (d, $\left.J=4.5 \mathrm{~Hz}, 3 \mathrm{H}, \mathrm{CH}_{3}\right) ;{ }^{13} \mathrm{C}-\mathrm{NMR}$ (DMSO) $\delta: 28.05,103.02,117.38$, 128.50, 129.17, 129.65, 129.86, 130.05, 135.89, 155.79, 168.36, 175.09, 190.21. IR cm ${ }^{-1}: 3257$, 3067, 1593, 1246, 1140. MS (ESI, $m / z$ ) [M-H] ${ }^{-}$calcd. for $\mathrm{C}_{13} \mathrm{H}_{9} \mathrm{~F}_{3} \mathrm{~N}_{4} \mathrm{~S}_{2}$ 341.0137; found 341.0232. Anal. calcd. C 45.61, H 2.65, N 16.36; found C 45.76, H 2.54, N 16.55\%.

7-(ethylamino)-3-phenyl-5-(trifluoromethyl)[1,3]thiazolo[4,5-d]pyrimidine-2(3H)-thione (4b). Yellow solid, yield 70\%, m.p. $217-218^{\circ} \mathrm{C} .{ }^{1} \mathrm{H}-\mathrm{NMR}$ (DMSO) $\delta: 8.81(\mathrm{t}, 1 \mathrm{H}, \mathrm{NH}), 7.59-7.39$ (m, 5H, Ar-H), 3.06-3.47 (q, 2H, $\left.\mathrm{CH}_{2}\right)$ 1.21-1.16 (t, 3H, $\left.\mathrm{CH}_{3}\right) ;{ }^{13} \mathrm{C}-\mathrm{NMR}$ (DMSO) $8: 14.64$, $36.19,129.17,129.54,129.63,129.84,130.01,133.85,135.93,153.23,153.71,155.08,155.80$, 
190.37. IR cm ${ }^{-1}$ : 3277, 2977, 2947, 2605, 1245, 1144, 734. MS (ESI, $\left.m / z\right)[\mathrm{M}-\mathrm{H}]^{-}$calcd. for $\mathrm{C}_{14} \mathrm{H}_{11} \mathrm{~F}_{3} \mathrm{~N}_{4} \mathrm{~S}_{2}$ 355.0293; found 355.0358. Anal. calcd. C 47.18, H 3.11, N 15.72; found C 47.08, H 3.41, N 15.12\%.

7-[(4-fluorobenzyl)amino)]-3-phenyl-5-(trifluoromethyl)[1,3]thiazolo[4,5-d]pyrimidine-2(3H)thione (4c). Gray solid, yield 70\%, m.p. 269-270 ${ }^{\circ} \mathrm{C} .{ }^{1} \mathrm{H}-\mathrm{NMR}$ (DMSO) $\delta: 8.91(\mathrm{t}, 1 \mathrm{H}, \mathrm{NH})$, 7.57-7.12 (m, 9H, Ar-H), ), $4.64\left(\mathrm{~d}, J=45.7 \mathrm{~Hz}, 2 \mathrm{H}, \mathrm{CH}_{2}\right) ;{ }^{13} \mathrm{C}-\mathrm{NMR}$ (DMSO) $\delta: ~ 43.72,115.41$, $115.69,115.98,129.58,129.65,130.21,130.32,130.80,130.84,131.74,131.85,133.84,135.31$, $135.35,155.73,160.223,163.44,168.25 . \mathrm{IR} \mathrm{cm}^{-1}: 3307,2963,1701,1155,732$. MS (ESI, $\left.m / z\right)$ [M-H] $]^{-}$calcd. for $\mathrm{C}_{19} \mathrm{H}_{12} \mathrm{~F}_{4} \mathrm{~N}_{4} \mathrm{~S}_{2}$ 435.0356; found 435.0546. Anal. calcd. C 52.29, H 2.77, N 12.84; found C $47.08, \mathrm{H} 3.41, \mathrm{~N} 15.12 \%$.

\subsubsection{X-ray Structural Studies}

Crystals of compound $\mathbf{2 e}$, suitable for single-crystal $X$-ray diffraction analysis, were grown by the slow evaporation of toluene at ambient temperature and in the presence of air.

Instead, to obtain $\mathbf{4 b}$ crystals, the solid was dissolved in methanol and propan-1-ol was added at any time until the solution turned cloudy and was allowed to slowly evaporate for several days. Diffraction data were collected with $\mathrm{Cu}-\mathrm{K}_{\alpha}$ radiation $(\lambda=1.5418 \AA)$ radiations ( $\omega$-scan modes) using a Rigaku Oxford Diffraction XtaLABSynergy-R DW diffractometer equipped with a HyPix ARC $150^{\circ}$ Hybrid Photon Counting (HPC) detector. The data were measured at 100(2) K by using an Oxford Cryosystems open-flow nitrogen cryostat. Data collection, cell refinement, data reduction and analysis were carried out with the CrysAlisPro software package [31]. Multi-scan absorption correction was applied to the data. The structures were solved by direct methods, using SHELXS-97 [32], and refined by a full-matrix least squares technique on F2 with SHELXL-2013 (and also with SHELXL2018) [33] with anisotropic thermal parameters for all non-H atoms. During the refinement for $\mathbf{2 e}$, toluene molecule was found to exhibit disorder about the center of symmetry. In both compounds, all $\mathrm{H}$ atoms were found in different Fourier maps and isotropically refine, but in the final refinement cycles, they were repositioned in their calculated positions and refined using a riding model in geometrically optimized positions, with $\mathrm{C}-\mathrm{H}=0.95 \AA$ (in $4 \mathbf{b}$ also 0.99 and $0.98 \AA$ for $\mathrm{CH}_{2}$ and $\mathrm{CH}_{3}$ ), and $\mathrm{U}_{\text {iso }}(\mathrm{H})=1.2 \mathrm{U}_{\text {eq }} \odot$ for $\mathrm{CH}$ (in $4 \mathrm{~b}$ also $1.2 \odot(\mathrm{C})$ for $\mathrm{CH}_{2}$ and $1.5 \mathrm{U}_{\mathrm{eq}}(\mathrm{C})$ for $\left.\mathrm{CH}_{3}\right)$; with $\mathrm{N}-\mathrm{H}=0.88 \AA$, and $\mathrm{U}_{\text {iso }}(\mathrm{H})=1.2 \mathrm{U}_{\mathrm{eq}}(\mathrm{N})$, respectively. All figures were made using the DIAMOND program [34]. An analysis of the intra- and intermolecular interactions was performed using the program PLATON [25]. Selected X-ray single-crystal data and structure refinement details are summarized in Table S1.

\subsection{Biological Activity}

\subsubsection{Antiproliferative Activity \\ Cell Lines}

To determine the antiproliferative activity of newly synthesized compounds, the following cell lines were used: human melanotic melanoma cell line (A375), human amelanotic melanoma cell line (C32), human breast adenocarcinoma cell line (MCF-7/WT), human prostate cancer androgen-independent (DU145) and two normal cell lines: hamster ovarian (CHO-K1) and immortalized human keratinocytes from histologically normal skin (HaCaT). The cells were obtained from the cell line bank of the Department of Molecular and Cellular Biology, Wroclaw Medical University. A375, C32, MCF-7/WT, DU145 and HaCaT cells were grown in a monolayer cultured in Dulbecco's Modified Eagle's Medium (DMEM, Sigma-Aldrich, Poznań, Poland), supplemented with 10\% of fetal bovine serum (FBS, Gibco, Paisley, UK) and 1\% of antibiotics (penicillin/streptomycin, Sigma-Aldrich) and $\mathrm{CHO}-\mathrm{K} 1$ were grown in HAM's F-12 medium (Sigma-Aldrich), supplemented with $10 \%$ fetal bovine serum (FBS, Gibco) and 1\% of antibiotics (penicillin/streptomycin, SigmaAldrich). Cell lines were cultured in the polystyrene flasks 25 or $75 \mathrm{~cm}^{2}$ (Thermo Fisher Scientific, Waltham, MA, USA), which were stored in $37{ }^{\circ} \mathrm{C}$ and $5 \% \mathrm{CO}_{2}$ in a humidified 95\% atmosphere (SteriCult, Thermo Scientific, Alab). The cell medium was exchanged 
twice a week. The exponentially growing cells were used throughout the experiments. The cells were rinsed with phosphate-buffered saline (PBS, Sigma-Aldrich) and trypsinized by Trypsin-EDTA $0.25 \%$ solution (Sigma-Aldrich).

\section{Cell Toxicity Test}

The influence of the compounds was performed in a monolayer culture on cancer and normal cells. Compounds were initially dissolved in DMSO; further dilutions of the compound were performed in Dulbecco's Modified Eagle's Medium supplemented with $10 \%$ FBS. Compounds were tested in a 50-5000 $\mu \mathrm{M}$ concentration range. In the in vitro experiments, the concentrations of DMSO in the final solution of the compounds were used $0.05 \% ; 0.1 \% ; 0.5 \% ; 1 \%$, respectively.

\section{Cell Viability Assays}

Cell viability was determined using the MTT colorimetric assay. All cell lines were seeded into 96-well plates to a density of $3 \times 10^{4}$ cells/well. After $24 \mathrm{~h}$, the culture supernatants were removed and appropriate dilutions of compounds in the culture medium (200 $\mu \mathrm{L} /$ well) were added to the cells' monolayer cultures and incubated for an additional $72 \mathrm{~h}$. After $72 \mathrm{~h}$ of exposition to the compounds and the removal of the culture medium, cell viability was determined by reducing the yellow dye 3-(4,5-dimethyl-2-thiazol)-2,5diphenyl-2H-tetrazolium bromide (MTT assay, Sigma Saint Louis, MO, USA; In Vitro Toxicology Assay) to a blue formazan product. The absorbance of the resulting solutions in three duplicate experiments was measured at the wavelength of $560 \mathrm{~nm}$ in a microplate reader (EnSpire, Perkin Elmer, Kraków, Poland). MTT assay is a colorimetric method that estimates the rate of metabolism in viable cells. Absorbance is directly proportional to the number of viable cells. All the experiments were performed three times and the mean absorbance values were calculated. The methodology for the evaluation of the growth of human cancer and normal cells was described previously [35]. The cell viability in each group was expressed as a percentage of control (untreated) cells.

\subsubsection{Anticancer Screening Methodology}

Primary Anticancer Assay and Determination of GI $_{50}$, TGI and LC 50 Values

The antitumor screening (NCI-60) was performed at the National Cancer Institute, Bethesda, USA. A total panel of approximately 60 human tumor cell lines derived from nine different cancer types (leukemia, non-small cell lung, colon, brain, melanoma, ovarian, renal, prostate and breast) formed the basis of this in vitro test. The origins and processing of the cell lines used in the study were described previously [26]. First, the compounds were evaluated in a primary anticancer assay at $10^{-5} \mathrm{M}$. Results for each tested compound are reported as the percent of growth of the treated cells. Compounds with significant growth inhibition of the cell lines were passed on for evaluation at five concentration levels $\left(10^{-4}, 10^{-5}, 10^{-6}, 10^{-7}\right.$ and $\left.10^{-8} \mathrm{M}\right)$. The human tumor cell lines of the cancer screening panel were grown in an RMPI 1640 medium containing 5\% fetal bovine serum and $2 \mathrm{mM}$ of L-glutamine. Each cell line was inoculated and preincubated at $37{ }^{\circ} \mathrm{C}, 5 \% \mathrm{CO}_{2}, 95 \%$ air and $100 \%$ relative humidity for $24 \mathrm{~h}$, before the addition of the test compound into 96-well microtiter plates in $100 \mu \mathrm{L}$ at plating densities ranging from 5000 to 40,000 cells/well. The density of inoculum depends on the type of tumor cell and its growth characteristics. The screened compounds were solubilized in dimethyl sulfoxide at 400-fold the desired final concentration and stored frozen. At the time of the test agents' addition, an aliquot of frozen concentrate was thawed and diluted to twice the desired final concentration with complete medium containing $50 \mu \mathrm{g} / \mathrm{mL}$ gentamicin. Next, the test compounds were evaluated at the four additional 10-fold dilutions to reach the final concentrations plus control. Aliquots of $100 \mu \mathrm{L}$ of the different dilutions $(100,10,1,01,001 \mu \mathrm{M} / \mathrm{mL})$ of the tested compounds were added to microtiter wells, and the culture was incubated for 48 $\mathrm{h}$ under the same conditions. Cell were fixed in situ by the addition of $50 \mu \mathrm{L}$ of cold $50 \%$ trichloroacetic acid and incubated for $60 \mathrm{~min}$ at $4{ }^{\circ} \mathrm{C}$. The supernatant was discarded; 
plates were washed five times with water and air-dried. Sulforhodamine B at $0.4 \%$ in $1 \%$ acetic acid, $100 \mu \mathrm{L}$, was added to each well, then plates were incubated for $10 \mathrm{~min}$ at room temperature. Unbound dye was removed by washing five times with $1 \%$ acetic acid and air dried. The protein-bound stain was solubilized with a $10 \mu \mathrm{M}$ trizma base and the absorbance was read on an automated plate reader. A wavelength of $515 \mathrm{~nm}$ was used to read optical densities. The cytotoxic effects were evaluated and results and dose-response parameters were calculated [27-29].

\section{Conclusions}

A series of the new 5-trifluoromethyl-2-thioxo-thiazolo[4,5- $d]$ pyrimidines 2a-e was synthesized by the cyclization of the 4-amino-2-thioxo-2,3-dihydro-3-substituted-1,3-thiazole5-carboxamides with trifluoroacetic anhydride. In the next step chlorination of 3a-e gave the 7-chloro derivatives 3a-e. Additionally, three 7-amino derivatives 4a-c were obtained by the treatment of compound $\mathbf{3 b}$ with methyl-, ethyl- and fluorobenzylamine. The structures were determined by IR, ${ }^{1} \mathrm{H}-\mathrm{NMR},{ }^{13} \mathrm{C}-\mathrm{NMR}, \mathrm{MS}$ and elemental analysis. Furthermore, compounds $2 \mathrm{e}$ and $\mathbf{4 b}$ were also studied by X-ray crystallography. Both compounds crystallized with one molecule in the asymmetric unit, but in two different space groups; thus, the packing of both crystals was varied. 2e molecules form dimers via N-H $\cdots$ O hydrogen bonds while $4 \mathrm{~b}$ molecules form a zig-zag chain due to the presence of $\mathrm{N}-\mathrm{H} \cdots \mathrm{S}$ hydrogen bonds. The crystal structures of both compounds are stabilized by weak C-H.F. C-H $\cdots S$ and $\pi \cdots \pi$ interactions.

The biological investigations (twelve compounds 2a-e, 3a-d and 4a-c) assessed the antiproliferative properties against human cancer (A375, C32, DU145, MCF-7/WT) and normal (CHO-K1 and $\mathrm{HaCaT}$ ) cell lines. An excellent antiproliferative activity was exhib-

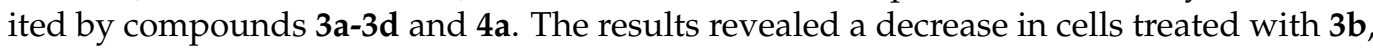
indicating that proliferation inhibited cancer cells. In normal human keratinocytes and hamster ovarian, a smaller or larger decrease in proliferation was observed depending on the compound. It was also shown that compounds 3a-3d (7-chloro) and 4a, with a small amino substituent, had a higher activity against human prostate, melanoma and were significantly less sensitive in normal fibroblasts. The increased activity of compounds $\mathbf{3 a - 3 \mathbf { d }}$ in comparison to compounds $\mathbf{2 a - 2 e}$ may result from their greater lipophilicity (Table 1) and the presence of a strongly electronegative substituent at position 7.

Four compounds, $\mathbf{2 b}, \mathbf{3 b}, \mathbf{4 b}$ and $\mathbf{4 c}$, selected by the National Cancer Institute, were used in a panel of approximately 60 human disease-oriented tumor cell lines in the anticancer screening. Among the screened compounds, only $\mathbf{3 b}$ demonstrated both cytostatic and cytotoxic activities, especially for leukemia and colon cancer cell lines.

New derivatives with a trifluoromethyl moiety were designed, with the hope of obtaining active compounds. Indeed, in the conducted research, the new derivatives 3a-3d and $4 \mathbf{a}$ were very active, especially compound $\mathbf{3 b}$. However, the trifluoromethyl moiety introduced into the structure of the new thiazolo [4,5-d] pyrimidine derivatives did not result in a significant increase in activity as compared to the derivatives with heterocyclic or aromatic substituents. The activity of the new compound $\mathbf{3 b}$ is comparable to its structural analogs. Together, these data indicate that newly developed 5-trifluoromethyl-2-thioxothiazolo[4,5- $d$ ]pyrimidine derivatives may be promising agents for further research and development as a prospective inhibitors in human cancer cells.

Supplementary Materials: The following supporting information can be downloaded at: https: / / www.mdpi.com/article/10.3390/ph15010092/s1, Figures S1-S15. ${ }^{1}$ H NMR spectra of compounds 1c, 1d, 2a-2e, 3a-e, 4a-c; Figures S16-S28. ${ }^{13} \mathrm{C}$ NMR spectra of compounds 2a-2e, 3a-e, 4a-c; Figures S29-S41. MS spectra of compounds 2a-2e, 3a-e, 4a-c; Figures S42-S54. IR spectra of compounds 2a-2e, 3a-e, 4a-c; Figure S55. The crystal packing of the $2 \mathbf{e}$ viewed along an axis. Disordered toluene molecules are marked with a purple wire/stick model. Dashed lines (in black) indicate intermolecular interactions, with $\mathrm{N}-\mathrm{H} \cdots \mathrm{O}$ in black, $\mathrm{C}-\mathrm{H} \cdots \mathrm{S}$ in orange and $\mathrm{C}-\mathrm{H} \cdots \mathrm{F}$ in light green; Table S1. Selected X-ray single-crystal data and structure refinement details of compounds $2 \mathbf{e}$ and $\mathbf{4 b}$. 


\begin{abstract}
Author Contributions: Conceptualization, L.B. and I.B.; methodology, L.B., A.P., N.R. and I.B.; software, L.B., A.P., N.R. and I.B.; validation, L.B., A.P., N.R. and I.B.; formal analysis, L.B. and I.B. and A.P.; investigation, L.B., A.P., N.R. and I.B.; resources, L.B., A.P., N.R. and I.B.; data curation, L.B., A.P., N.R. and I.B., writing—original draft preparation, L.B., A.P., N.R. and I.B.; writing-review and editing, L.B. and I.B.; visualization, L.B., A.P., N.R. and I.B.; supervision, L.B., and I.B.; project administration, L.B. and I.B.; funding acquisition, L.B., N.R. and I.B. All authors have read and agreed to the published version of the manuscript.
\end{abstract}

Funding: This research work was financially supported by the Wroclaw Medical University (grant number: SUB.D140.21.113).

Institutional Review Board Statement: Not applicable.

Informed Consent Statement: Not applicable.

Data Availability Statement: Data is contained within the article or Supplementary Materials.

Acknowledgments: The authors would like to thank Magdalena Maciejewska from the Institute of Immunology and Experimental Therapy (PAN, Wrocław) for her support regarding the DU 145 cells' culture. The authors thank the staff of the National Cancer Institute, Bethesda, MD, USA for conducting in vitro anti-cancer screening tests.

Conflicts of Interest: The authors declare no conflict of interest.

\title{
References
}

1. Hagmann, W.K. The Many Roles for Fluorine in Medicinal Chemistry. J. Med. Chem. 2008, 51, 4359-4369. [CrossRef]

2. Swallow, S. Chapter Two-Fluorine in Medicinal Chemistry. In Progress in Medicinal Chemistry, 1st ed.; Lawton, G., Witty, D.R., Eds.; Elsevier B.V.: London, UK, 2015; Volume 54, pp. 65-133. [CrossRef]

3. Böhm, H.-J.; Banner, D.; Bendels, S.; Kansy, M.; Kuhn, B.; Müller, K.; Obst-Sander, U.; Stahl, M. Fluorine in Medicinal Chemistry. ChemBioChem 2004, 5, 637-643. [CrossRef] [PubMed]

4. Müller, K.; Faeh, C.; Diederich, F. Fluorine in Pharmaceuticals: Looking Beyond Intuition. Science 2007, 317, 1881-1886. [CrossRef]

5. Kirk, K.L. Fluorine in Medicinal Chemistry: Recent Therapeutic Applications of Fluorinated Small Molecules. J. Fluor. Chem. 2006, 127, 1013-1029. [CrossRef]

6. Isanbor, C.; O’Hagan, D. Fluorine in Medicinal Chemistry: A Review of Anti-Cancer Agents. J. Fluor. Chem. 2006, 127, 303-319. [CrossRef]

7. Shah, P.; Westwell, A.D. The Role of Fluorine in Medicinal Chemistry. J. Enzym. Inhib. Med. Chem. 2007, 22, 527-540. [CrossRef] [PubMed]

8. Wolters, L.P.; Schyman, P.; Pavan, M.J.; Jorgensen, W.L.; Bickelhaupt, F.M.; Kozuch, S. The Many Faces of Halogen Bonding: A Review of Theoretical Models and Methods. WIREs Comput. Mol. Sci. 2014, 4, 523-540. [CrossRef]

9. Park, B.K.; Kitteringham, N.R.; O’Neill, O.P. Metabolism of Fluorine-Containing Drugs. Annu. Rev. Pharmacol. Toxicol. 2001, 41, 443-470. [CrossRef]

10. Purser, S.; Moore, P.R.; Swallow, S.; Gouverneur, V. Fluorine in Medicinal Chemistry. Chem. Soc. Rev. 2008, 37, 320-330. [CrossRef]

11. McClinton, M.A.; McClinton, D.A. Trifluoromethylations and Related Reactions in Organic Chemistry. Tetrahedron 1992, 48 , 6555-6666. [CrossRef]

12. Rugo, H.S.; Lerebours, F.; Ciruelos, E.; Drullinsky, P.; Ruiz-Borrego, M.; Neven, P.; Park, Y.H.; Prat, A.; Bachelot, T.; Juric, D.; et al. Alpelisib Plus Fulvestrant in PIK3CA-Mutated, Hormone Receptor-Positive Advanced Breast Cancer after a CDK4/6 Inhibitor (BYLieve): One Cohort of a Phase 2, Multicentre, Open-Label, Non-Comparative Study. Lancet Oncol. 2021, 22, 489-498. [CrossRef]

13. Möller, C.; Bone, W.; Cleve, A.; Klar, U.; Rotgeri, A.; Rottmann, A.; Schultze-Mosgau, M.H.; Wagenfeld, A.; Schwede, W. Discovery of Vilaprisan (BAY 1002670): A Highly Potent and Selective Progesterone Receptor Modulator Optimized for Gynecologic Therapies. ChemMedChem 2018, 13, 2271-2280. [CrossRef]

14. Rubaiya Nasrin, S.; Ishihara, T.; Md Rashedul Kabir, A.; Konagaya, A.; Sada, K.; Kakugo, A. Comparison of Microtubules Stabilized with the Anticancer Drugs Cevipabulin and Paclitaxel. Polym. J. 2020, 52, 969-976. [CrossRef]

15. Helsen, C.; Van Den Broeck, T.; Voet, A.; Prekovic, S.; Van Poppel, H.; Joniau, S.; Claessens, F. Androgen Receptor Antagonists for Prostate Cancer Therapy. Endocr. Relat. Cancer 2014, 21, T105-T118. [CrossRef]

16. Wilhelm, S.M.; Carter, C.; Tang, L.; Wilkie, D.; Mcnabola, A.; Rong, H.; Chen, C.; Zhang, X.; Vincent, P.; Mchugh, M.; et al. BAY 43-9006 Exhibits Broad Spectrum Oral Antitumor Activity and Targets the RAF/MEK/ERK Pathway and Receptor Tyrosine Kinases Involved in Tumor Progression and Angiogenesis. Cancer Res. 2004, 64, 7099-7109. [CrossRef]

17. Kuppast, B.; Fahmy, H. Thiazolo[4,5-d]Pyrimidines as a Privileged Scaffold in Drug Discovery. Eur. J. Med. Chem. 2016, 113, 198-213. [CrossRef]

18. Becan, L.; Wojcicka, A. 5-(3-Pyridinyl)Thiazole[4,5-d]Pyrimidine Derivatives: Synthesis and in Vitro Anticancer Evaluation. Acta Pol. Pharm. Drug Res. 2018, 75, 349-357. 
19. Becan, L.; Wagner, E. Synthesis and Anticancer Evaluation of Novel 3,5-Diaryl-Thiazolo[4,5-d]Pyrimidin-2-One Derivatives. Med. Chem. Res. 2013, 22, 2376-2384. [CrossRef] [PubMed]

20. Fahmy, H.T.Y.; Rostom, S.A.F.; Saudi, M.N.; Zjawiony, J.K.; Robins, D.J. Synthesis and In Vitro Evaluation of the Anticancer Activity of Novel Fluorinated Thiazolo[4,5-d]Pyrimidines. Arch. Pharm. 2003, 336, 216-225. [CrossRef] [PubMed]

21. Becan, L.; Wagner, E. Synthesis and Antitumor Screening of Novel 3-Phenylthiazolo[4,5- $d$ ]Pyrimidin-2-Thione Derivatives. Arzneim. Forsch. 2008, 58, 521-528. [CrossRef] [PubMed]

22. Gewald, K. Heterocyclen aus CH-aciden Nitrilen. VI. Reaktion von methylenaktiven Nitrilen mit Senfölen und Schwefel. J. Prakt. Chem. 1966, 32, 26-30. [CrossRef]

23. Lipinski, C.A.; Lombardo, F.; Dominy, B.W.; Feeney, P.J. Experimental and computational approaches to estimate solubility and permeability in drug discovery and development settings. Adv. Drug Deliv. Rev. 2001, 46, 3-26. [CrossRef]

24. Molinspiration Cheminformatics. Available online: https://www.molinspiration.com/cgi-bin/properties (accessed on 1 August 2021).

25. Speak, A.L. Single-crystal structure validation with the program PLATON. J. Appl. Cryst. 2003, 36, 7-13. [CrossRef]

26. Shoemaker, R.H. The NCI60 Human Tumour Cell Line Anticancer Drug Screen. Nat. Rev. Cancer 2006, 6, 813-823. [CrossRef] [PubMed]

27. Grever, M.; Schepartz, S.; Chabner, B. The National Cancer Institute: Cancer Drug Discovery and Development Program. Semin. Oncol. 1992, 19, 622-638. [PubMed]

28. Boyd, M.R. The NCI In Vitro Anticancer Drug Discovery Screen. In Anticancer Drug Development Guide: Preclinical Screening, Clinical Trials, and Approval; Teicher, B.A., Ed.; Humana Press: Totowa, NJ, USA, 1997; pp. 23-42. [CrossRef]

29. Alley, M.C.; Scudiero, D.A.; Monks, A.; Hursey, M.; Czerwinski, M.J.; Fine, D.L.; Abbott, B.J.; Mayo, J.G.; Shoemaker, R.; Boyd, M.R. Feasibility of Drug Screening with Panels of Human Tumor Cell Lines Using a Microculture Tetrazolium Assay. Cancer Res. 1988, 48, 584-588.

30. Devani, M.; Shishoo, C.; Pathak, U.; Parikh, S.; Radhakrishnan, A.; Padhya, A. Synthesis and Pharmacological Properties of Some 4-Amino-5-Substituted Thiazole-2(3H)-Thiones and Thiazolo(4,5-d)Pyrimidin-7(6H) One-2(3H)-Thiones. Arzneim. Forsch. 1977, 27, 1652-1655. [CrossRef]

31. CrysAlis PRO; Rigaku Oxford Diffraction: Yarnton, UK, 2020.

32. Sheldrick, G.M. A Short History of SHELX. Acta Cryst A 2008, 64, 112-122. [CrossRef]

33. Sheldrick, G.M. Crystal Structure Refinement with SHELXL. Acta Cryst C 2015, 71, 3-8. [CrossRef]

34. Brandenburg, K. DIAMOND; Crystal Impact GbR: Bonn, Germany, 2012.

35. Drag-Zalesinska, M.; Drag, M.; Poręba, M.; Borska, S.; Kulbacka, J.; Saczko, J. Anticancer properties of ester derivatives of betulin in human metastatic melanoma cells (Me-45). Cancer Cell Int. 2017, 17, 4. [CrossRef] [PubMed] 